\title{
Posttraumatic stress disorder (PTSD), anger and Mental health of school students in Syria after ten years of conflict: a large scale school-based study
}

\author{
Ameer Kakaje ( $\square$ ameer.kakaje@hotmail.com ) \\ Damascus University, faculty of medicine https://orcid.org/0000-0002-3949-6109 \\ Ragheed Al Zohbi \\ Aleppo University, faculty of medicine \\ Ayham Alyousbashi \\ Damascus University, faculty of medicine \\ Rawan N. K. Abdelwahed \\ Damascus University, faculty of medicine \\ Osama Hosam Aldeen \\ Damascus University, faculty of medicine \\ Mohammad Marwan Alhalabi \\ Damascus University, faculty of medicine \\ Ayham Ghareeb \\ Damascus University, faculty of medicine \\ Youssef Latifeh
}

(3) Department of Internal Medicine, Division of Psychiatry, Al-Mowasat University Hospital, Damascus Syria

\section{Research Article}

Keywords: Mental health; PTSD; health-related quality of life; anger; CRIES-13; DAR-5; Syria; war; conflict; school students; children; Syrian crisis.

Posted Date: May 6th, 2020

DOl: https://doi.org/10.21203/rs.3.rs-27218/v1

License: (c) (1) This work is licensed under a Creative Commons Attribution 4.0 International License. Read Full License

Version of Record: A version of this preprint was published on December 3rd, 2020. See the published version at https://doi.org/10.1017/S0033291720003761. 


\section{Abstract}

The Syrian crisis has entered its tenth year with incessant conflicts in many locations across Syria. Much of the population have been impacted including children who suffer the direct and indirect war effects of war. To date there has been no large scale study examining the mental health and academic impacts of the war of children in Syria. This large-scale cross-sectional study aims to evaluate the psychological profile of school students in Damascus Syria examining PTSD, anger and general mental health and examine their relationships with work, smoking and academic performance. The study included 1369 students from seven different schools. Surveys included assessment of mental and physical well-being using a measure of health related quality of life (SF8), Posttraumatic stress disorder (CRIES-13), problematic anger (DAR5) smoking, working habits, social support and academic grades. The study found that more than half of the children suffered from PTSD (53\%), problematic anger (62\%) with this being associated with poorer SF-8 (quality of life) scores in both mental and physical domains and more time watching TV and Internet. Around $46 \%$ declared fair or worse general health and $61 \%$ having moderate or severe mental health. War variables had an impact on PTSD, anger, and SF-8, but not an impact on grades. Worse HRQL was associated with war variables and smoking. Social support was negatively correlated with SF-8, PTSD, DAR-5 anger and declarations of close friends being the main source of support. This is the largest study of children is Syria to date that reports on the psychological ramification of war. The study demonstrates the severe impact on children across both mental health and physical health. Although direct war effect could not be observed, the high burden of PTSD and anger distress is a strong reflection of the chronic mental trauma. School students have had to work and face many hurdles in a young age which has left them severely impacted.

\section{Introduction}

The Syrian crisis remains complex and dynamic after it entered its tenth year. Syrians have suffered major tragedies affecting all aspects of their lives. It is estimated that 11.1 million people need humanitarian assistance in Syria and the north-west region is still under conflict with over than 950,000 being displaced and 2.7 million dependent on humanitarian assistance. More than 5.5 million have fled the country as refugees and 6 million were internally displaced. Approximately, eight out of ten people in Syria live below poverty line [1, 2]. Depleted savings, loss of income, displacement to seek safety, deprivation of education, starvation, and limited health service have all been fundamental threats potentially impacting the wellbeing of the Syrian population.

People involved in life-threatening events or exposed to the risk of physical injury to self or others can suffer from a serious psychological trauma and experience post-traumatic stress disorder (PTSD) [3]. Higher prevalence of PTSD was found in people who encountered a traumatic event and/or were exposed to the war in Syria [4]. PTSD symptoms lead to considerable impairment and severely disrupt social, occupational, and educational performance and functioning. Additionally further psychiatric disturbances may result as complications of PTSD such as mood and anxiety disorders, and dependence on addictive substances [5], with war exposure variables in Syria identified as correlated with cigarette and shisha smoking [6]. Furthermore, PTSD sufferers may develop somatoform complications manifesting as chronic pain, health deterioration, greater vulnerability to medical problems, and increased numbers of medical disorders [5] such as major non-malignant gastric-tract disorder [7]. Moreover, war-related distress was found to correlate with allergic rhinitis [8] and laryngopharyngeal reflux [9].

Children depend on adults who love them to provide them with empathy, care, and attention. Conflicts frequently disrupt attachments in various ways such as the loss of parents, parents' extreme concentration on protecting and providing the essential needs for the family, and lack of parents' emotional support due to depression or distraction [10]. Children may be forced into substitute care with less attentive or caring relatives or an orphanage. Alternatively children may become deprived of all adult protection as "unaccompanied children" [10]. Children who are required to move into refugee or displacement camps may suffer for years from catastrophic circumstances while waiting to resume their normal life [10]. Given this we can define conflicts as a major global public health threat [10].

While there has been some attention to rates of PTSD in Syria [4], few studies have been concerned with the status of children [11-13]. These studies found that higher social support was correlated with a lower probability of having PTSD $[4,14]$. However these existing studies suffer from considerable limitations. The Syrian adult population samples were limited to the people who were online and saw the survey [4]; the one school study was mostly focused on oral health and while included a measure of PTSD not include any other mental health components and [12] or other school study involved the city of Damascus and Latakia which were much less affected than other cities from war and contained many less displaced people with the studied population in Damascus being limited to 247 participants from 5 schools with $67.9 \%$ not responding to war-related questions. Furthermore, they included age group of (8-15) years with students in elementary schools comprising the largest proportion while not mentioning schools locations.

The importance of intervention in reducing the psychological impact of distressing events has been long recognized [15], therefore it is crucial to detect mental reactions early in children and youth to put into place appropriate preventive strategies that targetthe social and psychological factors which have been demonstrated to predict long term mental health disorders [16]. High rates of socioeconomic deprivation impose a substantial need for mental health care for suffering populations, but only provide scarce accessibility for them [17]. Furthermore, the stigma associated with mental disorders limits the use of available resources [17]. Studies have indicated that further systematic data collection are required to address the needs of the internally displaced populations in order to enhance their physical and mental health through upgrading health system services [18]. It is fundamental to evaluate the efficacy of healthcare programs and interventions while great constrains are imposed on health care such as declined aid budgets, decreased access to health care services, and less affordable drugs are present to treat diseases of those living in conflict zones [19].

In this study, PTSD, anger, and health-related quality of life (HRQL) were evaluated among children in grade 10 or higher in Damascus in schools. In addition factors including smoking, socioeconomic status, working, war variables, TV and internet time were also assessed. The study aims to determine the behaviours and the psychological profile of children who spent ten years of their life at war and how it affected their mental health and their daily lives. This

Page 2/17 
study was conducted directly before the lock down of the county on 13/03/2020 and before any confirmed cases of COVID-19 in Syria which indicates a minimum effect if the virus on the general population. Our study is the first to measure war zone related health-related quality of life, anger and examine the effects that PTSD and other mental health factors have on educational gains..

\section{Methods}

\section{1) Sampling:}

Our study is a cross-sectional study conducted in Syria from 1/3/2020 to 12/3/2020. Surveys in Arabic were distributed in Damascus public schools which were divided into four areas: East, West, North, and South. No surveys were distributed in public schools in the Eastern region due to the unexpected lock down. Only participants who lived in Syria and attended its schools for the past ten years were enrolled. Schools were randomly chosen from each area while balancing gender distribution as most public schools are unisex. Only student in grade ten or higher were enrolled regardless of age. Students were also randomly chosen from classes. Surveys were distributed in school classes to avoid the interference of other family members while answering with at least two skilled data collectors remained in classes to assure anonymity and to explain if something was not clear for the student.

\section{2) Consent and approval for study:}

Written consent was given from the caregivers before proceeding with the survey by one week when children were younger than 18 years, and for using and publishing the data. Written consent was also taken when the participant was 18 years or older. Confidentiality was assured and no identity-revealing questions were asked. Oral consent was also taken from children before giving the survey regardless of age.

Our study protocol and ethical aspect were reviewed and approved by Damascus University, faculty of medicine ethic committee in Damascus, Syria. It was also approved by Damascus University vice president for scientific affair, Damascus University faculty of medicine vice dean for scientific affairs, and by minister of education.

\section{3) Questionnaires:}

\section{- Socioeconomic status (SES):}

SES was assessed through three criteria; (1) the education level and profession of the participant or the working family members, (2) the monthly family income of the participant if they were living alone, or of the house provider if living in family. SES was then divided into four different categories: lower, upper lower, middle, and upper.

\section{- Health-related quality of life (HRQL):}

An Arabic version of the self-reported HRQL SF-8 was used to evaluate the general health, the physical functioning, physical role, body pain, the vitality, social functioning, mental-health, and emotional-role [20,21]. SF 8 is a short measure for large population and is used to assess the general physical and mental health. It can be used in a population which was affected by a conflict. We used a version with five point responses as the first item answers of "fair" and "good" were combined into fair and the fourth item answers of "mild" and "moderate" were combined into "moderate" [21]. Items (1-4) measured the physical component summary (PCS), and items (5-8) measured the mental component summary (MCS).

\section{- Social support:}

An Arabic version of Multidimensional Scale of Perceived Social Support (MSPSS) [22, 23] was used to measure the support that the individual receives from their social network including friends, family, and significant other [22, 23]. Only one presentative question was used as the survey was meant to be short. The questions, that were in Arabic, were: "I get the emotional help \& support I need from my family", "I have a special person who is a real source of comfort to me", and "I have friends with whom I can share my joys and sorrows". Only scores were used for comparisons.

\section{- PTSD:}

An Arabic version of children's impact of event scale (13) CRIES-13 was used, which is a self-reporting screening method for PTSD that can be used in children aged eight years and older [24, 25]. It contains four items to measure intrusion, four items to measure avoidance, and five items to measure arousal. For PTSD screening, the results of intrusion and avoidance are used, and therefore their score without arousal is determined for PTSD screening. If the sum of the two scales is 17 or more, there is a high probability of the child having PTSD. The score of arousal was only used in this study as a score without setting a cut-off. CRIES-13, however, is based on diagnostic and statistical manual of mental disorders IV (DSM IV) [21, 26]. These three clusters, intrusion, arousal, and avoidance, are close to what is used in the International Classification of Disease 11 (ICD-11) criteria. However, using DSM IV criteria relatively diagnoses less severe traumatic cases [27].

Each item had four answers with four point scale; not at all=0, rarely=1, sometimes=3, and often=5.

\section{- Anger.}

Dimensions of anger reactions 5 (DAR-5) was used to assess the frequency, intensity, duration of anger in the last four weeks. It is also used to assess the aggression and the impact that the anger had on social functioning. It is a self-reported measure that contains 5 items and has a scale ranging (1-5). When 
the sum of these five items is above 12, it is an indication that the person has anger-related physiological distress and functional impairment [28, 29]. However, there is no Arabic version of DAR- 5 and therefore we translated it and used it in the survey.

\section{- Other Questions:}

Gender, province of origin, age and having consanguineous parents were some of the questions asked. Direct and indirect variables about war were identified, such as changing residency, being distressed or endangered, and losing someone close. Having a long standing medical condition was also collected. Third-degree consanguinity was defined as first cousins. Fourth-degree consanguinity was defined as second cousins, and second cousins once removed.

We asked questions about working; its reasons, time, type, years of working, if they liked their work, if they believed that their work significantly affected their study, and if they think that their boss was mean to them. We asked how many people are currently living in your house, and if the house was rented. We asked about the ninth grade marks as it is a national exam with unified questions across the country which could give a more accurate estimation if the marks differed between students.

We asked about smoking habits, whether they regularly and daily smoked cigarettes, shisha, or other, average number of cigarettes per day for the last month, and average number of shisha smoked per week. We asked about the reason for smoking and if they felt peer pressured into smoking, if they felt like adults when smoking, and the preferred time of shisha smoking. We asked about average time spent in hours each week on TV, or internet.

\section{4) Data Process:}

Data was processed using IBM SPSS software version 26 for Windows (SPSS Inc, IL, USA). Chi-square, one-way analysis of variance (ANOVA), and independent-t tests were performed to determine statistical significance between the groups. Pearson correlation was also calculated. Through the same software, odds ratios (ORs) and the $95 \%$ confidence intervals for the groups were calculated using Mantel-Haenszel test. Values of less than 0.05 for the two-tailed $\mathrm{P}$ values were considered statistically significant.

\section{Results}

\section{- General characteristics:}

In this study, 1369 students agreed to participate from seven different schools, two of which were in the northern area, two in the western area, and three in the southern area. It included 723 males and 646 females, of which 244 males and 349 females were from the northern area, 142 males and 205 females from the western area, and 337 males and 92 females from the southern area with a mean age of (16.38 \pm 0.79$)$ years. Major characteristics of these children with PTSD, and anger prevalence, HRQL 8 individual questions and PCS, and MCS scores are in (Table 1). Of note here is that the prevalence of PTSD was $53 \%$ and problematic anger $62.2 \%$. According to SF $8,46 \%$ have moderately to severely affected general health, $30.9 \%$ have somewhat limited physical functioning or worse, $30.9 \%$ have somewhat or more difficult to work from physical role, $35.3 \%$ have moderate to severe bodily pain, $29.4 \%$ have some energy or less, $29.1 \%$ have limited social functioning, $61 \%$ have moderate to severe negative mental health, and $32.5 \%$ have negative role-emotional. PTSD and anger prevalence according to gender and school districts are demonstrated in (Figure 1).

\section{- Health-related quality of life (HRQL):}

Each individual question: All SF-8 results items were correlated with female gender with body pain, vitality, social functioning, mental-health, and emotionalrole $(P<0.001)$, and general health $(P=0.002)$, physical role $(P=0.014)$, and physical functioning $(P>0.05)$. Poorer individual $S F-8$ question results were also correlated with having a chronic medical condition with $(P<0.05)$. Interestingly, better mental health score was correlated with consanguineous parents $(P=0.011)$ while other SF-8 questions had $(P>0.05)$ with consanguineous parents. All SF-8 results were correlated with having work at $(P<0.001)$ except for social functioning $(P=0.018)$, body pain $(P=0.052)$, physical finding $(P=0.388)$. None of the reported reasons for working were statistical significance with SF-8 results $(P>0.05)$. Declaring that the employer was mean and education being affected from work were correlated with poorer $S F-8$ results $(P<0.01)$ and $(P<0.001)$, respectively. There was no correlation between the house being rented and SF-8 results $(P>0.05)$.

Poorer SF-8 outcomes were all statistically significantly correlated with high probability of PTSD, higher arousal score, higher DAR-5 anger scores, and weaker family support at $(P<0.001)$. SF-8 single questions had correlations with all social support and DAR-5 ( $r< \pm 0.3)$, and for PTSD ( $r>0.3)$ except for physical functioning all with $(\mathrm{P}<0.001)$. All these results are demonstrated in (Table 2$)$ in more details.

Poorer SF-8 results were found in responders with chronic medical condition ( $\mathrm{P}<0.01$ for all SF-8 results). This was particularly in responders with cardiac or urinary medical condition. When comparing having a chronic medical condition or not with SF-8 results, all the results we significantly correlated with having a chronic medical condition $(\mathrm{P}<0.001)$.

Frequency of weekly smoking shisha and number of close people lost from war were statistically significant correlated $(P<0.05)$ with worse physical role $(r=-0.132$, and $r=-0.153$, respectively) and worse vitality ( $r=-0.131$, and $r=-0.153$, respectively). Other SF-8 results had correlations ( $r \leq \pm 0.1)$ with number of people living in the house, number of years failed in schools, SES scores, working years, number of cigarettes and shisha smoked, number of residences changed due to war and number of close individuals lost from war.

Cigarette and shisha smoking and being a previous smoker were correlated with all SF-8 results $(P<0.001)$ except for vitality $(P=0.086)$. Being distressed from war and being endangered from war were correlated with poorer SF-8 results with $(P<0.01)$ (except for physical functioning and its relation to being 
distressed from war which had $(P=0.019)$.

Physical and Mental Components (PCS and MCS): In examining the combination of the items into the PCS and MCS subscales, we observed that both scales were highly corralated $(r=0.526$ at $P<0.001)$. Different characteristics of PCS and MCS scores in students are demonstrated in (Table 4). Being distressed from war and endangered from war were significantly correlated with higher PCS and MCS scores $(P<0.001)$. Changing place of living was also correlated with higher PCS $(P=0.006)$, and MCS $(P=0.012)$ scores. Having two or more positive of the previous three war variables had the mean PCS score of $15.17 \pm 3.193$ and the mean MCS score of $14.12 \pm 3.478$. Being endangered from war had the highest mean PCS and MCS scores. PCS and MCS scores significant differences in regards to PTSD, anger, arousal, social support are demonstrated in (Table 2).

Conducting forward linear regression on PCS scores was significant with these $(P<0.05)$ with DAR 5 anger, having a chronic medical condition, losing someone due to war, family support, being distressed from war noises, working, and gender all contributing significantly with $\mathrm{R}$ square values indicating these variables contributed $7.7 \%, 2.6 \%, 1.3 \%$, and $0.5 \% .0 .5 \%, 0.5 \%$, and $0.5 \%$, respectively to the PCS variance with $\mathrm{DAR}-5$ anger scores recording (P<0.001). When doing forward linear regression on PCS scores with PTSD scores and the previous variables, $(P<0.05)$ for PTSD scores, having a chronic medical condition, losing someone due to war, working, and family support with R square of $8.2 \%, 2.7 \%, 1.2 \%, 1.0 \%$, and $0.4 \%$, respectively with PTSD scores having $(\mathrm{P}<0.001)$.

Conducting forward linear regression on MCS scores with DAR 5 scores, DAR 5 anger, gender, family support, being endangered from war, working, having a chronic medical condition, being distressed from war noise, significant other support and friends support all contributed significantly $(P<0.05)$ with $R$ square values indicating these variables contributed $13.2 \%, 2.3 \%, 2.3 \%, 1.3 \%, 1.1 \%, 0.5 \%, 0.4 \%, 0.3 \%$ and $0.3 \%$ to the MCS variance respectively with the DAR 5 score recording $(\mathrm{P}<0.001)$. When using regression on MCS scores with the PTSD (intrusion + avoidance) score and the other previous variables, $(\mathrm{P}<0.05)$ for PTSD scores, family support, having a chronic medical condition, being endangered from war, gender, and working with $\mathrm{R}$ square of $19.5 \%, 2.0 \%, 0.8 \%, 0.5 \%$, $0.5 \%$, and $1.2 \%$, respectively with PTSD scores having $(P<0.001)$.

\section{- PTSD:}

PTSD prevalence was 53\% with arousal mean score of 9.46. Correlations between PTSD and SF-8 was discussed in the previous paragraph, and demonstrated in (Table 2). Correlations between CRIES-13 and DAR-5 are demonstrated in (Table 3). PTSD (intrusion + avoidance) and arousal scores correlations with other variables are demonstrated in (Table 4) and (Table 5). Other variables and PTSD were demonstrated in (Table 5).

Forward linear regression on PTSD scores was significant $(P<0.001)$ with DAR 5 anger score, gender, family support, being endangered from war, distressed from war noises, and changing place of living due to war recording R squares indicating contributions of $8.2 \%, 6.1 \%, 1.0 \%, 0.9 \%, 0.8 \%$, and $0.3 \%$ to the variance in PTSD scores respectively. When using forward linear regression on PTSD scores with the same previous variables except for social support, R square value was $8.5 \%$ for DAR 5 .

\section{- Anger.}

Problematic anger was seen in $62.2 \%$. DAR 5 correlation with SF-8 and PTSD were demonstrated in previous paragraphs. More distress from anger was correlated with family support ( $r=-0.161)$ and friends support $(r=-0.098)$ (Table 3). Other variables were demonstrated in (Table 4). Dar-5 scores were also correlated with more hours spent on TV and the Internet (Table 5).

\section{- Other variables:}

Gender and consanguinity: Having parents of fourth degree consanguinity and more distant relatives were correlated with more numbers of people living in the house $(\mathrm{P}<0.001)$. However, consanguinity was not correlated with higher family support or any social support. Female gender had higher SES groups than males $(P<0.001)$ while there was no difference in the house being rented or not between gender $(P>0.05)$. Moreover, males worked for more years, and failed more years at school than females ( $P<0.001$ for both). However, males watch TV for less hours while spending more hours on Internet ( $=0.007$, and $\mathrm{P}=0.298$, respectively). Males smoke cigarette, and cigarette with shisha more than females $(\mathrm{P}<0.001)$ with males smoking more cigarettes (mean for females was 8.9 while for males was $13, P=0.041)$. More females ( 616 out of 642 ) did not have a work than males $(245$ out of 719$)(P<0.001)$. Males failed more years than females $[(P<0.001)$ with mean for males $(0.07)$ years and for females $(0.03)]$. Females expressed more distress from war noises than males $[\mathrm{P}<0.001$ (OR, 4.632; 95\% Cl, 3.629-5.912)], but there was no difference in being endangered from war between genders $(P>0.05)$.

School performance: Ninth grade marks were correlated with PTSD (intrusion + avoidance) score ( $r=0.074$ and $P=0.009)$, with family support ( $r=0.076$ and $\mathrm{P}=0.008)$ while not significantly correlated with arousal score, DAR-5 anger scores, and other social supports $(P>0.05)$. Living in a rented house, losing someone due to war, or being endangered from war had no statistical significant difference in marks $(P>0.05)$. Interestingly, students being distressed from war had a significantly higher mean of ninth grade mark by $7(2.6 \%)$ points $(P=0.002)$. and females reported higher mean grades than males by 18 ( $5.8 \%)$ points $(P<0.001)$. Having work was correlated with having lower grades (over than 15 points $P<0.001)$. We also found a statistical significant difference when comparing type of work and grades $(\mathrm{P}<0.001)$ which is demonstrated in (Figure 2). Smoking cigarette and/or shisha was correlated with lower grades by a mean of $6(1.94 \%)$ points in shisha and $11(3.5 \%)$ points in cigarette $(\mathrm{P}<0.002)$. There was a difference in mean grades of different SES groups as the high SES groups had higher marks $(\mathrm{P}<0.001)$ and the difference between the mean grade of the lower SES and Upper SES was around 25 points $(8.1 \%)$. Forward linear Regressing DAR 5 scores, family, friends, and significant other support scores, PTSD scores, gender, working, and all war variables of distress from noises, being endangered, and changing place of living on grades was significant but $(P<0.001)$ only gender and working contributed significantly to the variance in grades recording $\mathrm{R}$ squares of $5.9 \%$, and $1.6 \%$, respectively. 
Socioeconomic status (SES): In our sample, there was no statistical significant difference in gender and living in a rented house, but there was in SES groups as females were in higher SES groups than males $(P<0.001)$. Moreover, in higher SES groups, students tended not to work more frequently $(P<0.001)$. Working was also correlated with cigarette and/or shisha smoking $(P<0.001)$. Lower SES was found with smoking but $(P=0.061)$. However, living in rented house was correlated with smoking, mainly cigarettes and cigarette with shisha $(P=0.019)$. More students from Southern area schools lived in rented houses $(P=0.005)$ and from Northern area were in higher SES groups $(P<0.001)$.

Other variables: The mean number of people that the students can depend on to provide them with support was $1.02 \pm 0.427$. Around $17 \%$ declared that at least one parent was the main source of the support, $11.5 \%$ a sibling, $15 \%$ someone they loved, and $39.9 \%$ a close friend.

\section{Discussion}

Critically this study found that the prevalence of PTSD (intrusion + avoidance) was as high as $53.0 \%$ and $62 \%$ for problematic anger, with elevated mean of arousal scores (9.46). Moreover, one third of students were either previous smokers or current smokers. Around half of students had to change place of living due to war, $58 \%$ reported that they were directly endangered from the war, $61 \%$ had distress from war noises, and $40 \%$ had lost someone close due to war. Around one third had to work, mainly in summer times and holidays (including week-ends). It is clear therefore from this study which is the largest of its kind in Syria to assess for PTSD, anger, mental and physical health more generally that this is a highly impacted population.

\section{- PTSD:}

War trauma experience which manifests as losing someone or being endangered was correlated with higher PTSD prevalence [30]. PTSD when left untreated can become chronic and thus affecting the psychosocial development and functioning in adulthood. Therefore, actions are needed to be taken as a very large population of children in Syria was affected in this ten-year war [31]. Although this study did not involve the high-risk population, more than half of the children were screened positive for PTSD which will have devastating outcomes in the future.

PTSD prevalence in our study was over than half of children with female predominance which was somewhat less than another study conducted on Syrian population adults which used DSM-IV questionnaire similar to our study [4]. Another study in Damascus schools which included 811 children found that the prevalence can be up to $90 \%$ with variable degrees and this study also used a DSM-IV bases questionnaire [12]. Another study which used CRIES-8, similarly to our study, included 492 children aging between 8 and 15 years from schools in Damascus and Latakia with $35.1 \%$ having PTSD, 32\% having depression, and $29.5 \%$ having anxiety [11]. It also found a female predominance similar to our study which is well known [32]. A study on Syrian schoolchildren refugees in Jordan found that $31 \%$ had moderate to severe PTSD with female predominance [33]. Another study in Lebanon and Jordan children refugees found that 45.6\% have developed PTSD [34]. These differences in prevalence in studies in Syria and outside Syria may reflect that the internal displacement and persistent trauma had a more sever effect than being a refugee in a foreign country [4].

Moreover, as more than half of Syrian screened positive for PTSD in a previous study which did not involve high-risk population too [4], this will provide an extra risk as they may have symptoms when raising their child for years. Even when parents exhibit symptoms of PTSD acutely, this can contribute to developing persistent PTSD in children [35]. PTSD can also go for years without being recognised by the parents and PTSD in children is largely shaped by the parents' own acute traumatic stress which was a response to the child's trauma [35].

As more than half of this study had at least one positive war variable and even higher prevalence of war variables were found in many studies of the Syrian population and that this exposure had many ramifications to different health aspects $[4,6,8,9,11,12]$.

\section{- Anger:}

Anger can affect recovery and is associated with significant distress and impact on functioning [28, 29]. Some responders who would not admit they have been psychologically and emotionally affected from trauma will express these emotions in anger which is the reason why screening for anger might be as important and indeed more sensitive as screening for PTSD. Anger association with SF-8 and CRIES 13 was discussed in previous paragraphs. Anger in children can also be a part of oppositional defiant disorder and conduct disorder [30].

Anger was associated with smoking which may indicate that having distress from anger may predispose to smoking. This anger was not statistically significantly correlated with gender, SES, having chronic medical conditions, working, or with type of work. It was with multiple variables of war. Anger was also associated with more hours spent on TV and Internet.

DAR 5 is a useful tool for differentiating people with PTSD who would score high or low in State Trait Anger Expression Inventory-2 (STAXI 2 ) and in PCL for posttraumatic stress scores [28]. STAXI is the golden standard for anger but it is long to be used and DAR-5 is now used in many countries such as the UK, the US and Australia and recently translated into and tested in French [36]. Dar 15 was used to assess problematic anger and it showed higher level of PTSD, psychological distress and lower levels of quality of life [37].

Anger has been addressed as an important factor in PTSD as anger is one of the criteria for arousal symptom cluster of PTSD and other studies found that anger is important to determine PTSD severity. It was also noted that $40 \%$ of PTSD score variance is attributed to anger. However, its impact exceeds being attributed to one PTSD criterion [38]. Anger was significant in a particular PTSD population such as crime victims and survivors of torture [38-40].

Anger was found to be associated with lower mental and physical component in SF-12. Higher prevalence of personality disorders, substance abuse, and any psychiatric disorder [41]. Inappropriate anger prevalence in the US was found to be around $7.8 \%$. with a male predominance [41] which was different from our study as no significant difference was found with gender. 


\section{- Health-related quality of life (HRQL):}

All HRQL of SF-8 were negatively affected by PTSD, arousal, and anger. Female gender and having chronic medical conditions also negatively affected SF-8 while consanguineous parents had positive effects. This could not be explained by having larger families or more support as when they were compared with SF-8, they had no significant correlation. Moreover, less distress from anger was reported when having consanguineous parents which also could not be explained. Smoking was also correlated with poor HRQL, but we could not determine causation.

When using forward linear regression, MCS has affected PTSD score by $19.7 \%$, and DAR 5 score by $13.7 \%$. PCS had affected DAR 5 score by $9.4 \%$ and PTSD score by $8.5 \%$.

SF 8 can be used for measurements of general physical and mental health in conflicts and internally displaced population [21, 42]. It was found to be a good measurement in programs for HRQL [43] and hence it was used in this study to provide baseline data for current programs and future studies. In the study of conflict and internally displaced population of 1206 adults, SF-8 was found to have a correlation with PTSD and depression [42]. They used a DSMIII based questionnaire which could explain the differences to our study which found a correlation in only social functioning, mental health, and emotional role while the others had a correlation. Furthermore, the population in that study had been in war for 20 years with older age groups and the samples were from camps. Another study in Iraq which used SF-8 and DSM-4 for PTSD which is similar to our study found no significant differences in SF-8 between the group with low PTSD and high PTSD [42]. However, they used a smaller sample with also different age from our study. The high prevalence of abnormal mental health is in no doubt troublesome; this high prevalence was found among adults in another study where severe mental health was in $44.7 \%$ of the population who was living in Syria [4].

Most scores on individual question of PCS and MCS were lower than what was found in Iraq [21]. However, that study comprised of 52 participants and they were chosen out of 408 as they had the lowest and highest score on PTSD measure. SF-8, mainly MCS, can reflect the psychological burden in the community, especially as depression and PTSD were screened and found to be very high in the Syrian community and that around $44.7 \%$ were screened positively for severe mental disorder [4].

\section{Other Variables:}

More males were working while being student than females. This could be from the society encouraging males to work and help their parents while discouraging females from working, especially at young ages. Another hypothesis can be that although no differences were found in being the house rented or not and gender, there were differences in estimated SES which could explain why males worked more or because males failed more years so they had to find a work. Females tended to spend more time on TV, while males spent more time on the Internet. Males were also found to smoke more and tend to smoke shisha with cigarette more frequently than females. These findings can simply result from females' fear of admitting the truth of actually being smokers, but this is unlikely as they were assured that their answers will remain anonymous. Around one third of school students are regular cigarette and/or shisha smokers. Students who had more distress from anger tended to smoke more.

Although being distressed from war was correlated with higher marks, When using forward linear regression, marks were only correlated with gender and working. We could not also determine whether working started after the ninth class grade or before it. Schools from some regions suffered less from PTSD as they are from higher SES and they are less likely to have suffered from war which could explain differences in PTSD, anger, and SF-8.

A study in Iraq demonstrated that $94 \%$ of the sampled was exposed to at least one traumatic event [21]. As smoking in our study was correlated with lower grades, working when was a school student, and living in a rented house or being in lower SES, it was found that in Syria over than one-third is a regular smoker [6] which is similar to our study which demonstrates no big difference between school students and adults in smoking prevalence. Smoking was also found to be correlated with allergic rhinitis [8], and laryngopharyngeal reflux in Syria which were all correlated with being distressed from war noises.

\section{Limitations:}

- This study was conducted in Damascus, not in areas that were more severely affected. Furthermore, this study was conducted in public schools without students from private schools and children who dropped out or had to drop out from trauma from war. This all indicate that this study has underestimated the true prevalence of PTSD and other war variables.

- This study could not cover more areas due to COVID-19 outbreak worldwide and Syria going to lock down.

- Only screening surveys were used; no clinical diagnosis could be used due to unavailability of resources.

- There was no valid scale of SES due to no scale could be practically used in Syria due to different salaries and the social values that refuse to declare all financial income.

- The participants were left with the freedom of answering whatever questionnaire they chose, meaning there were some participants who would answer a questionnaire while leaving the other.

- Could not indicate when the events of war occurred in relation to the time of questionnaire.

- The psychiatric aspect of the parents could not be assessed.

- School performance was only assessed by one exam which although it is unified, it cannot alone determine the performance of the student, especially that most students will work very hard to excel at this particular exam.

\section{Conclusion}


More than half of Syrian students in schools were screened positive for PTSD and distress from anger while social support played little role. The high prevalence of abnormal mental health and general health indicate a serious disaster as these are the young generation. Around one third had only some energy and around one quarter found it difficult to work. Females were affected more. War was significantly associated with worse HRQL, either mentally or physically. Students with PTSD had more problems from anger, were exposed more to war, and tend to do negative habits more often such as cigarette and shisha smoking and spending more time on TV and the Internet. The high PTSD prevalence while having relatively low overall SF-8 scores may suggest that children who grew up in traumatic events may cope better and get used to it that they may exhibit or express lower evaluation of their days and themselves in PCS and MCS while adults may have worse adaptation methods. Meanwhile, PTSD and anger burden grow heavier in the consecutive years.

Consanguinity and type of work had different effects on PTSD and anger distress. Social support had correlations with PTSD, HRQL, and anger. Students who had distress from anger tended to smoke more, but not to smoke larger quantities. Students who had distress from anger also used the internet by 9 hours more than who did not have distress. Interestingly, work was correlated with better PTSD, but worse PCS. Interestingly, war variables did not have a significant effect on school performance.

More studies are needed to determine whether working of children and the type of work had a real effect on their education, work and school grades and whether war had a direct effect on studying too as this paper could not find such a relation. Also, other studies are needed to evaluate parents' psychological effect on their children.

\section{Abbreviations}

\begin{tabular}{ll} 
COVID-19 & Coronavirus disease of 2019 \\
\hline CRIES & Children's impact of event scale \\
\hline DAR & Dimensions of anger reactions \\
\hline DSM & Diagnostic and statistical manual of mental disorders \\
\hline HRQL & Health-related quality of life \\
\hline ICD & International Classification of Disease \\
& \\
\hline MCS & Mental component summary \\
\hline MSPSS & Multidimensional Scale of Perceived Social Support \\
\hline PCS & Physical component summary \\
\hline PTSD & Post-traumatic stress disorder \\
\hline SES & Socioeconomic status \\
\hline SF & Short Form \\
\hline STAXI 2 & State Trait Anger Expression Inventory-2
\end{tabular}

\section{Declarations}

\section{Ethics approval and consent to participate:}

Our study protocol and ethical aspect were reviewed and approved by Damascus University, faculty of medicine ethic committee in Damascus, Syria. It was also approved by Damascus University vice president for scientific affair, Damascus University faculty of medicine vice dean for scientific affairs, and by minister of education.

Written consent was given from the caregivers before proceeding with the survey by one week when children were younger than 18 years, and for using and publishing the data. Written consent was also taken when the participant was 18 years or older. Confidentiality was assured and no identity-revealing questions were asked. Another oral consent was also taken from the students before giving the survey regardless of age.

\section{Consent for publication:}

Written consent for using and publishing the data was taken before participating in the research from the caregiver when the student was younger than 18 years and from the student when was 18 years or older.

\section{Availability of data and materials:}

The data can be made available upon reasonable request.

\section{Competing interests:}

We have no conflict of interest to declare. 


\section{Funding:}

We received no funding in any form.

\section{Authors' contributions:}

AK: Conceptualization; Data curation; Formal analysis; Investigation; Methodology; Project administration; Supervision; Resources; Validation; original draft; Writing - review \& editing.

RAZ: Investigation; Project administration; Supervision; Resources; Methodology

AA: Investigation; Data curation; Methodology; Formal analysis; Software; Data curation.

RNKA: Investigation; original draft; Writing - review \& editing

OHA: Investigation; Resources; Project administration

MMA: Methodology; Validation; Software; Conceptualization.

AG: Software; Resources; Conceptualization.

YL: Supervision; Resources; Validation.

All authors have read and approved the manuscript.

\section{Acknowledgements:}

We would like to thank doctors Mohammad Abd Al-Hakeem Kiwan MD, Mazen Abdalhamid Al Janadi MD, and Ahmeh Abdulrazak Haj Ersan MD for their aid in making this research possible and facilitating its conduction, and distribution of the surveys and making sure that data collecting was valid and anonymous.

\section{References}

1. United Nations Office for the Coordination of Humanitarian Affairs (UNOCHA) (2020) Syria crisis overview. 16/04/2020]; Available from: https://www.unocha.org/syrian-arab-republic/about-ocha-syria.

2. Agency., C.g.C.I. MIDDLE EAST :: SYRIA. FEBRUARY 20, 2020 [cited 2020 29th of February]; Available from: https://www.cia.gov/library/publications/resources/the-world-factbook/geos/sy.html.

3. Yehuda, R. and J. LeDoux, Response variation following trauma: a translational neuroscience approach to understanding PTSD. Neuron, 2007. 56(1): $\mathrm{p}$. 19-32.

4. Kakaje, A., et al., Mental disorder and PTSD in Syria during wartime: a national-wide crisis. 2020.

5. (UK)., N.C.C.f.M.H., Post-Traumatic Stress Disorder: The Management of PTSD in Adults and Children in Primary and Secondary Care. Leicester (UK): Gaskell; 2005. (NICE Clinical Guidelines, No. 26.) 2, Post-traumatic stress disorder.

6. Kakaje, A., et al., Smoking habits in Syria and the influence of war on cigarette and shisha smoking. 2020.

7. Gradus, J.L., et al., Posttraumatic Stress Disorder and Gastrointestinal Disorders in the Danish Population. Epidemiology, 2017. 28(3): p. 354-360.

8. Kakaje, A., et al., Allergic rhinitis and its epidemiological distribution in Syria: a high prevalence and additional risks in war time. 2020.

9. Kakaje, A., et al., Prevalence of Laryngopharyngeal Reflux Disease in War-torn Syria and its Association with Smoking and other Risks. 2020.

10. Santa Barbara, J., Impact of war on children and imperative to end war. Croat Med J, 2006. 47(6): p. 891-4.

11. Perkins, J.D., et al., Mental health in Syrian children with a focus on post-traumatic stress: a cross-sectional study from Syrian schools. Social Psychiatry and Psychiatric Epidemiology, 2018. 53(11): p. 1231-1239.

12. Bahaa Aldin Alhaffar, M.H., et al., Seven years of war in Syria: The relation between oral health and PTSD among children. Indian Journal of Oral Health and Research, 2018. 4(1).

13. Alhaffar, B.A., et al., Oral health and socio-economic status among children during Syrian crisis: a cross-sectional study. BMC Oral Health, 2019. 19(1).

14. Simon, N., et al., Associations between perceived social support, posttraumatic stress disorder (PTSD) and complex PTSD (CPTSD): implications for treatment. European Journal of Psychotraumatology, 2019. 10(1).

15. Tol, W.A., et al., Mental health and psychosocial support in humanitarian settings: linking practice and research. The Lancet, 2011. 378(9802): p. 15811591.

16. Montgomery, E., Trauma, exile and mental health in young refugees. Acta Psychiatr Scand Suppl, 2011(440): p. 1-46.

17. Saxena, S., et al., Resources for mental health: scarcity, inequity, and inefficiency. The Lancet, 2007. 370(9590): p. 878-889.

18. Bashour, H., Let's Not Forget the Health of the Syrians Within Their Own Country. American Journal of Public Health, 2015. 105(12): p. 2407-2408.

19. Coutts, A., et al., Responding to the Syrian health crisis: the need for data and research. The Lancet Respiratory Medicine, 2015. 3(3): p. e8-e9.

20. Ware, J., et al., How to score and interpret single-item health status measures: a manual for users of the SF-8 health survey. 2001. 
21. Aljurany, K.A.H., Personality characteristics, trauma and symptoms of PTSD: a population study in Iraq. 2013, Heriot-Watt University.

22. Zimet, G., Multidimensional Scale of Perceived Social Support (MSPSS) - Scale Items and Scoring Information. 2016.

23. R, M. and S. Kazarian, Validation of the Arabic translation of the Multidensional Scale of Social Support (Arabic MSPSS) in a Lebanese community sample. Arab Journal of Psychiatry, 2012. 23: p. 159-168.

24. Perrin, S., R. Meiser-Stedman, and P. Smith, The Children's Revised Impact of Event Scale (CRIES): Validity as a Screening Instrument for PTSD. Behavioural and Cognitive Psychotherapy, 2005. 33(4): p. 487-498.

25. Child Revised Impact of Events Scale. April 2017 17/04/2020]; Available from: https://www.corc.uk.net/outcome-experience-measures/child-revisedimpact-of-events-scale/.

26. Carlson, E.B., Psychometric Study of a Brief Screen for PTSD:Assessing the Impact of Multiple Traumatic Events. Assessment, 2016. 8(4): p. 431-441.

27. Haravuori, H., et al., An evaluation of ICD-11 posttraumatic stress disorder criteria in two samples of adolescents and young adults exposed to mass shootings: factor analysis and comparisons to ICD-10 and DSM-IV. BMC Psychiatry, 2016. 16(1).

28. Forbes, D., et al., Utility of the Dimensions of Anger Reactions-5 (Dar-5) Scale as a Brief Anger Measure. Depression and Anxiety, 2014. 31(2): p. 166-173.

29. Forbes, D., et al., A concise measure of anger in combat-related posttraumatic stress disorder. Journal of Traumatic Stress, 2004. 17(3): p. 249-256.

30. Association, A.P., Diagnostic and statistical manual of mental disorders (DSM-5®). 2013: American Psychiatric Pub.

31. Kolaitis, G., Trauma and post-traumatic stress disorder in children and adolescents. European Journal of Psychotraumatology, 2017. 8(sup4).

32. Rosenfield, S. and D. Mouzon, Handbook of Sociology and SocialResearch. 2013.

33. Beni Yonis, O., et al., Post-traumatic stress disorder among Syrian adolescent refugees in Jordan. J Public Health (Oxf), 2019.

34. Khamis, V., Posttraumatic stress disorder and emotion dysregulation among Syrian refugee children and adolescents resettled in Lebanon and Jordan. Child Abuse \& Neglect, 2019. 89: p. 29-39.

35. Meiser-Stedman, R., et al., Posttraumatic Stress Disorder in Young Children 3 Years Posttrauma. The Journal of Clinical Psychiatry, 2017. 78(3): p. 334339.

36. Ceschi, G., et al., Posttraumatic anger: a confirmatory factor analysis of the Dimensions of Anger Reactions Scale-5 (DAR-5) - French adaptation. European Journal of Psychotraumatology, 2020. 11(1).

37. Forbes, D., et al., Evaluation of the Dimensions of Anger Reactions-5 (DAR-5) Scale in combat veterans with posttraumatic stress disorder. Journal of Anxiety Disorders, 2014. 28(8): p. 830-835.

38. McHugh, T., et al., Anger in PTSD: Is there a need for a concept of PTSD-related posttraumatic anger? Clinical Psychology Review, 2012. 32(2): p. 93-104. 39. Cahill, S.P., et al., Effect of Cognitive-Behavioral Treatments for PTSD on Anger. Journal of Cognitive Psychotherapy, 2003. 17(2): p. 113-131.

40. Dunnegan, S.W., Violence, Trauma and Substance Abuse. Journal of Psychoactive Drugs, 2011. 29(4): p. 345-351.

41. Okuda, M., et al., Prevalence and correlates of anger in the community: results from a national survey. CNS Spectrums, 2014. 20(2): p. $130-139$.

42. Roberts, B., et al., The reliability and validity of the SF-8 with a conflict-affected population in northern Uganda. Health and Quality of Life Outcomes, 2008. 6(1).

43. Lefante, J.J., et al., Use of the SF-8 to assess health-related quality of life for a chronically ill, low-income population participating in the Central Louisiana Medication Access Program (CMAP). Quality of Life Research, 2005. 14(3): p. 665-673.

\section{Tables}


TABLE 1

Characteristics of the subjects with their responses to the questions and frequencies.

\begin{tabular}{|c|c|c|c|}
\hline Characteristic & $\begin{array}{l}\text { Frequency } \\
\text { (Percentage\%) }\end{array}$ & Characteristic & Frequency (Percentage\%) \\
\hline \multirow{3}{*}{$\begin{array}{c}\text { Gender } \\
\text { Male } \\
\text { Female }\end{array}$} & & Being distressed from the war noises & \\
\hline & $723(52.8)$ & No & $516(39.0)$ \\
\hline & $646(47.2)$ & Yes & $807(61.0)$ \\
\hline Class & & Type of work: & \\
\hline $10^{\text {th }}$ grade & $648(47.4)$ & Waiter & $55(4.0)$ \\
\hline $11^{\text {th }}$ grade & $646(47.2)$ & Education & $6(0.4)$ \\
\hline $12^{\text {th }}$ grade & $74(5.4)$ & Retail Worker & $186(13.6)$ \\
\hline District of origin & & In an office & $15(1.1)$ \\
\hline Damascus, Rif-Dimashq, and Aleppo & $833(64.0)$ & Labourer & $36(2.6)$ \\
\hline Homs and Hama & $99(7.6)$ & Handicraft & $92(6.7)$ \\
\hline Al-Jazira region & $62(4.8)$ & Industry & $21(1.5)$ \\
\hline Southern Syria & $74(5.7)$ & Design & $7(0.5)$ \\
\hline Syrian coast & $155(11.9)$ & Chef & $2(0.1)$ \\
\hline Idlib & $15(1.2)$ & Prefer Not to Say & $80(5.8)$ \\
\hline Other & $63(4.8)$ & Losing someone due to the war & \\
\hline Consanguinity & & No & $734(60.2)$ \\
\hline No & $1020(75.8)$ & One close person & $409(33.5)$ \\
\hline Yes third-degree relatives & $158(11.7)$ & Two close persons & $57(4.7)$ \\
\hline Yes fourth-degree relatives & $64(4.8)$ & Three close persons & $16(1.3)$ \\
\hline Yes but not close relatives & $103(7.7)$ & Four close persons or more & $4(0.3)$ \\
\hline Schools according to zones & & Were you directly endangered from the war? & \\
\hline Northern area & $593(43.3)$ & No & $553(42.0)$ \\
\hline Southern area & $429(31.3)$ & Yes & $763(58.0)$ \\
\hline Western area & $347(25.3)$ & Changing place of living due to war & \\
\hline Chronic Medical Conditions & & No & $629(47.8)$ \\
\hline Negative & $1104(86.0)$ & Yes & $687(52.2)$ \\
\hline Gastroenterology & $5(0.4)$ & Do you regularly smoke? & \\
\hline Pulmonology & $9(0.7)$ & No & $907(66.9)$ \\
\hline Cardiology & $16(1.2)$ & Yes cigarettes & $69(5.1)$ \\
\hline Endocrinology & $25(1.9)$ & Yes shisha & $248(18.3)$ \\
\hline Urology & $6(0.5)$ & Yes, both & $111(8.2)$ \\
\hline Nervous & $17(1.3)$ & Yes, other & $6(0.4)$ \\
\hline Skeletal & $16(1.2)$ & Former smoke & $14(1.0)$ \\
\hline Asthma & $22(1.7)$ & Reported feeling peer-pressured into smoking & \\
\hline Allergy & $35(2.7)$ & No & $208(83.9)$ \\
\hline Ophthalmology & $10(0.8)$ & Yes & $40(16.1)$ \\
\hline Psychiatry & $2(0.2)$ & Reported feeling more adult when smoking & \\
\hline Other & $1(0.1)$ & No & $224(92.9)$ \\
\hline Two and more & $15(1.2)$ & Yes & $17(7.1)$ \\
\hline House & & Reported main reason for smoking & \\
\hline Rented & $315(23.9)$ & For psychological relief & $64(50.4)$ \\
\hline Owned & $1004(76.1)$ & For entertainment & $63(49.6)$ \\
\hline SES Groups & & & \\
\hline Lower & $16(1.3)$ & & \\
\hline Upper lower & $269(21.2)$ & Characteristic & Mean (SD) \\
\hline Lower middle & $475(37.4)$ & Age & $16.38(0.790)$ \\
\hline Upper middle & $466(36.7)$ & Number of people living in the house & $5.86(7.750)$ \\
\hline Upper & $43(3.4)$ & Number of working years (for people who have worked) & $2.89(1.895)$ \\
\hline Working & & Number of failed years in school & \\
\hline Yes but only in summer times & $861(63.3)$ & Number of times changing place of living due to war & $0.05(0.257)$ \\
\hline $\begin{array}{l}\text { Yes, but only in summer times } \\
\text { Yes in summer and holidays (week-ends) }\end{array}$ & $295(21.7)$ & Average cigarettes smoked daily for smokers & \\
\hline Yes, all year long & $105(7.7)$ & Average Shisha smoked weekly for smokers & $1.21(1.791)$ \\
\hline Other times & $5(0.4)$ & Average weekly hours spent on TV & $12.29(10.739)$ \\
\hline Denged & & $\begin{array}{l}\text { Average weekty nours spent on tne internet } \\
\text { DAR } 5 \text { score }\end{array}$ & $17.01(16.274)$ \\
\hline $\begin{array}{l}\text { Reported that working has affected their } \\
\text { studies significantly }\end{array}$ & & Arousal score & $30.01(61.113)$ \\
\hline No & & Avoidance score & $14.70(5.099)$ \\
\hline Yes & $388(78.4)$ & Intrusion score & $9.46(5.679)$ \\
\hline Reported that they liked their job & $107(21.0)$ & Family support score & $8.52(6.022)$ \\
\hline No & 103 & Significant other support score & $8.38(5.508)$ \\
\hline Yes & $382(78.8)$ & Friends support score & $4.91(2.077)$ \\
\hline Reported reason for working & & & $5.53(2.051)$ \\
\hline Entertainment & & & $5.32(2.089)$ \\
\hline To learn or develop a skill & $140(32.4)$ & Characteristic & $\mathrm{CI}=95 \%$ \\
\hline To provide personal expenses & $111(24.7)$ & PTSD (Avoidance + Intrusion) Prevalence & $53.0 \%(50.4-55.8) 62.2 \%$ \\
\hline To help with family expenses & $139(30.9)$ & Positive DAR 5 Prevalence & $(59.6-64.7)$ \\
\hline Forced by the Family & $4(0.9)$ & Mean Physical Component Summary (PCS) score & $15.51(15.34-15.67)$ \\
\hline Other reason & $3(0.7)$ & Mean Mental Component Summary (MCS) score & $14.57(14.40-14.76)$ \\
\hline
\end{tabular}




\begin{tabular}{|l} 
Reported being treated badly by boss \\
Yes \\
No \\
Preferred time of smoking \\
With friends \\
Morning \\
Evening \\
Undetermined
\end{tabular}

64 (86.5)

$410(13.5)$

$244(64.4)$

$7(1.8)$

$48(12.7)$

$80(21.1)$
Declaring having fair general health or worse

Somewhat or quite limited physical functioning or worse

Finding somewhat or more difficult to work from physical

health (role physical)

Having moderate bodily pain or worse

Declaring having some energy or less (Vitality)

Declaring having somewhat or quite limited social functioning

(or worse)

Having moderate mental health or worse

Having somewhat or more negative role-emotional
$46 \%(43.5-48.5)$

$30.9 \%(28.5-33.2)$

$26.5 \%(24.2-28.9$ (

$35.3 \%(33.0-37.9)$

$29.4 \%(26.9-31.8)$

$29.1 \%(26.7-31.5)$

$61.0 \%(58.2-63.5)$

$32.5 \%(30.0-35.2)$

Table 2

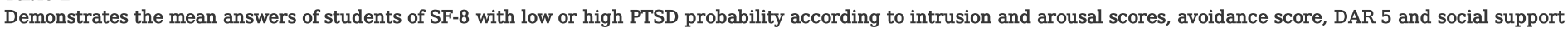
scores.

\begin{tabular}{|c|c|c|c|c|c|c|c|c|c|c|c|c|}
\hline $\begin{array}{l}\text { Health- } \\
\text { related } \\
\text { quality of } \\
\text { life } \\
\text { subscale }\end{array}$ & $\begin{array}{c}\text { Low } \\
\text { Probable } \\
\text { PTSD } \\
\text { Group } \\
\text { M (SD) }\end{array}$ & $\begin{array}{c}\text { High } \\
\text { Probable } \\
\text { PTSD } \\
\text { Group } \\
\text { M (SD) }\end{array}$ & $\begin{array}{c}\mathrm{P} \\
\text { value }^{\mathrm{a}}\end{array}$ & $\begin{array}{c}\text { P value } \\
\text { (correlation) }^{b}\end{array}$ & $\begin{array}{c}\text { Arousal }^{\mathrm{c}} \\
\text { P value } \\
\text { (correlation) }\end{array}$ & $\begin{array}{c}\text { Negative } \\
\text { DAR } 5 \\
\text { M (SD) }\end{array}$ & $\begin{array}{c}\text { Positive } \\
\text { DAR } 5 \\
\text { M (SD) }\end{array}$ & $\begin{array}{c}P \\
\text { value }^{d}\end{array}$ & $\begin{array}{c}\text { P value } \\
\text { (correlation) }^{\mathrm{e}}\end{array}$ & $\begin{array}{c}\text { Family } \\
\text { support }^{\mathrm{f}} \\
\text { P value } \\
\text { (correlation) }\end{array}$ & $\begin{array}{l}\text { Significant } \\
\text { other } \\
\text { support }^{\mathrm{f}} \\
\text { P value } \\
\text { (correlation) }\end{array}$ & $\begin{array}{l}\text { Friends } \\
\text { Support } \\
\text { P value } \\
\text { (correlation) }\end{array}$ \\
\hline $\begin{array}{c}\text { General } \\
\text { health }\end{array}$ & $\begin{array}{l}3.80 \\
(0.87) \\
\end{array}$ & $\begin{array}{c}3.43 \\
(0.951) \\
\end{array}$ & $<0.001$ & $\begin{array}{c}<0.001 \\
(r=0.239)\end{array}$ & $\begin{array}{c}<0.001 \\
(r=-0.303)\end{array}$ & $\begin{array}{c}3.77 \\
(0.869) \\
\end{array}$ & $\begin{array}{c}3.51 \\
(0.960)\end{array}$ & $<0.001$ & $\begin{array}{c}<0.001 \\
(\mathrm{r}=-0.197)\end{array}$ & $\begin{array}{c}<0.001 \\
(\mathrm{r}=0.118)\end{array}$ & $\begin{array}{c}0.796 \\
(\mathrm{r}=0.007)\end{array}$ & $\begin{array}{c}0.003 \\
(\mathrm{r}=0.081)\end{array}$ \\
\hline $\begin{array}{c}\text { Physical } \\
\text { functioning }\end{array}$ & $\begin{array}{c}4.27 \\
(0.992) \\
\end{array}$ & $\begin{array}{c}3.94 \\
(1.124)\end{array}$ & $<0.001$ & $\begin{array}{c}<0.001 \\
(\mathrm{r}=0.180)\end{array}$ & $\begin{array}{c}<0.001 \\
(\mathrm{r}=-0.255)\end{array}$ & $4.33(0.986)$ & $\begin{array}{c}3.95 \\
(1.110)\end{array}$ & $<0.001$ & $\begin{array}{c}<0.001 \\
(\mathrm{r}=0.206)\end{array}$ & $\begin{array}{c}<0.001 \\
(\mathrm{r}=0.103)\end{array}$ & $\begin{array}{c}0.978 \\
(\mathrm{r}=0.001)\end{array}$ & $\begin{array}{c}0.004 \\
(\mathrm{r}=0.078)\end{array}$ \\
\hline $\begin{array}{c}\text { Role- } \\
\text { physical }\end{array}$ & $\begin{array}{c}4.35 \\
(0 . .903)\end{array}$ & $\begin{array}{c}3.88 \\
(1.090)\end{array}$ & $<0.001$ & $\begin{array}{c}<0.001 \\
(\mathrm{r}=0.269)\end{array}$ & $\begin{array}{c}<0.001 \\
(\mathrm{r}=-0.303)\end{array}$ & $\begin{array}{c}4.33 \\
(0.898)\end{array}$ & $\begin{array}{c}3.95 \\
(1.082)\end{array}$ & $<0.001$ & $\begin{array}{c}<0.001 \\
(\mathrm{r}=0.218)\end{array}$ & $\begin{array}{c}<0.001 \\
(\mathrm{r}=0.116)\end{array}$ & $\begin{array}{c}0.358 \\
(\mathrm{r}=0.025)\end{array}$ & $\begin{array}{c}<0.001 \\
(\mathrm{r}=0.090)\end{array}$ \\
\hline Bodily pain & $\begin{array}{c}4.08 \\
(0.899) \\
\end{array}$ & $\begin{array}{c}3.72 \\
(1.045) \\
\end{array}$ & $<0.001$ & $\begin{array}{c}<0.001 \\
(\mathrm{r}=0 .-237) \\
\end{array}$ & $\begin{array}{c}<0.001 \\
(\mathrm{r}=-0.312)\end{array}$ & $\begin{array}{c}4.11 \\
(0.900) \\
\end{array}$ & $\begin{array}{c}3.76 \\
(1.025) \\
\end{array}$ & $<0.001$ & $\begin{array}{c}<0.001 \\
(r=0.214)\end{array}$ & $\begin{array}{c}<0.001 \\
(\mathrm{r}=0.108)\end{array}$ & $\begin{array}{c}0.760 \\
(\mathrm{r}=-0.008) \\
\end{array}$ & $\begin{array}{c}0.468 \\
(\mathrm{r}=0.020) \\
\end{array}$ \\
\hline Vitality & $\begin{array}{c}3.98 \\
(0.826) \\
\end{array}$ & $\begin{array}{c}3.58 \\
(0.986) \\
\end{array}$ & $<0.001$ & $\begin{array}{c}<0.001 \\
(\mathrm{r}=-0.261)\end{array}$ & $\begin{array}{c}<0.001 \\
(\mathrm{r}=-0.361)\end{array}$ & $\begin{array}{c}3.94 \\
(0.801) \\
\end{array}$ & $\begin{array}{c}3.66 \\
(0.992) \\
\end{array}$ & $<0.001$ & $\begin{array}{c}<0.001 \\
(\mathrm{r}=0.209)\end{array}$ & $\begin{array}{c}<0.001 \\
(\mathrm{r}=0.119)\end{array}$ & $\begin{array}{c}0.012 \\
(\mathrm{r}=0.069)\end{array}$ & $\begin{array}{c}<0.001 \\
(\mathrm{r}=0.114)\end{array}$ \\
\hline $\begin{array}{c}\text { Social } \\
\text { functioning }\end{array}$ & $\begin{array}{c}4.31 \\
(0.947) \\
\end{array}$ & $\begin{array}{c}3.73 \\
(1.172) \\
\end{array}$ & $<0.001$ & $\begin{array}{c}<0.001 \\
(\mathrm{r}=-0.308)\end{array}$ & $\begin{array}{c}<0.001 \\
(\mathrm{r}=-0.351)\end{array}$ & $\begin{array}{c}4.32 \\
(0.918) \\
\end{array}$ & $\begin{array}{c}3.80 \\
(1.173) \\
\end{array}$ & $<0.001$ & $\begin{array}{c}<0.001 \\
(\mathrm{r}=0.290)\end{array}$ & $\begin{array}{c}<0.001 \\
(\mathrm{r}=0.143)\end{array}$ & $\begin{array}{c}0.192 \\
(\mathrm{r}=-0.036)\end{array}$ & $\begin{array}{c}0.543 \\
(\mathrm{r}=0.017)\end{array}$ \\
\hline $\begin{array}{l}\text { Mental } \\
\text { health }\end{array}$ & $\begin{array}{c}3.44 \\
(1.197) \\
\end{array}$ & $\begin{array}{c}2.68 \\
(1.233) \\
\end{array}$ & $<0.001$ & $\begin{array}{c}<0.001 \\
(\mathrm{r}=-0.368)\end{array}$ & $\begin{array}{c}<0.001 \\
(\mathrm{r}=-0.418)\end{array}$ & $\begin{array}{c}3.41 \\
(1.186) \\
\end{array}$ & $\begin{array}{c}2.82 \\
(1.278) \\
\end{array}$ & $<0.001$ & $\begin{array}{c}<0.001 \\
(r=0.281)\end{array}$ & $\begin{array}{c}<0.001 \\
(\mathrm{r}=0.160)\end{array}$ & $\begin{array}{c}0.185 \\
(\mathrm{r}=-0.036) \\
\end{array}$ & $\begin{array}{c}0.053 \\
(r=0.053) \\
\end{array}$ \\
\hline $\begin{array}{c}\text { Role- } \\
\text { emotional }\end{array}$ & $\begin{array}{c}4.22 \\
(1.027)\end{array}$ & $\begin{array}{c}3.55 \\
(1.189)\end{array}$ & $<0.001$ & $\begin{array}{c}<0.001 \\
(\mathrm{r}=-0.362)\end{array}$ & $\begin{array}{c}<0.001 \\
(\mathrm{r}=-0.431)\end{array}$ & $\begin{array}{c}4.21 \\
(1.010)\end{array}$ & $\begin{array}{c}3.66 \\
(1.198)\end{array}$ & $<0.001$ & $\begin{array}{c}<0.001 \\
(\mathrm{r}=0.295)\end{array}$ & $\begin{array}{c}<0.001 \\
(\mathrm{r}=0.196)\end{array}$ & $\begin{array}{c}0.504 \\
(r=-0.018)\end{array}$ & $\begin{array}{c}<0.001 \\
(\mathrm{r}=0.099)\end{array}$ \\
\hline PCS & $\begin{array}{c}16.26 \\
(2.861) \\
\end{array}$ & $\begin{array}{c}14.84 \\
(3.294) \\
\end{array}$ & $<0.001$ & $\begin{array}{c}<0.001 \\
(\mathrm{r}=-0.268)\end{array}$ & $\begin{array}{c}<0.001 \\
(\mathrm{r}=-0.348)\end{array}$ & $\begin{array}{c}16.32 \\
(2.887)\end{array}$ & $\begin{array}{c}15.01 \\
(3.257) \\
\end{array}$ & $<0.001$ & $\begin{array}{c}<0.001 \\
(\mathrm{r}=0.280)\end{array}$ & $\begin{array}{c}<0.001 \\
(\mathrm{r}=0.143)\end{array}$ & $\begin{array}{c}0.751 \\
(\mathrm{r}=0.009)\end{array}$ & $\begin{array}{c}0.001 \\
(\mathrm{r}=0.088)\end{array}$ \\
\hline MCS & $\begin{array}{c}15.86 \\
(2.953) \\
\end{array}$ & $\begin{array}{c}13.42 \\
(3.442)\end{array}$ & $<0.001$ & $\begin{array}{c}<0.0010 \\
(r=-0.424)\end{array}$ & $\begin{array}{c}<0.001 \\
(\mathrm{r}=-0.506)\end{array}$ & $\begin{array}{c}15.76 \\
(2.890) \\
\end{array}$ & $\begin{array}{c}13.84 \\
(3.542) \\
\end{array}$ & $<0.001$ & $\begin{array}{c}<0.001 \\
(\mathrm{r}=0.360)\end{array}$ & $\begin{array}{c}<0.001 \\
(\mathrm{r}=0.207)\end{array}$ & $\begin{array}{c}0.741 \\
(\mathrm{r}=-0.009) \\
\end{array}$ & $\begin{array}{c}0.001 \\
(\mathrm{r}=0.095)\end{array}$ \\
\hline
\end{tabular}

MCS: Mental Component Summary; PCS: Physical component Summary.

${ }^{\text {a }} \mathrm{P}$ value is calculated by using independent sample t-test between the subscale and low and high PTSD group.

${ }^{\mathrm{b}} \mathrm{P}$ value is calculated by using Pearson correlation between the subscale and intrusion + avoidance scores.

${ }^{\mathrm{c}} \mathrm{P}$ value is calculated by using Pearson correlation between the subscale and arousal score.

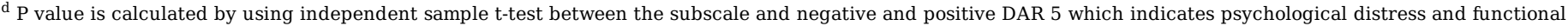
impairment related to anger.

e $\mathrm{P}$ value is calculated by using Pearson correlation between the subscale and DAR 5 score.

${ }^{\mathrm{f}} \mathrm{P}$ value is calculated by using Pearson correlation between the subscale and support score.

\section{Figures}


Table 3

Demonstrates DAR 5 and social support correlations with PTSD (intrusion + avoidance) and arousal score

\begin{tabular}{|c|c|c|c|c|c|c|c|}
\hline & $\begin{array}{c}\text { Negative DAR } \\
5 \\
M(\mathrm{SD})\end{array}$ & $\begin{array}{c}\text { Positive DAR } \\
5 \\
M(\mathrm{SD})\end{array}$ & $P$ value ${ }^{a}$ & $\begin{array}{c}\text { P value } \\
\text { (correlation) }^{\mathrm{b}}\end{array}$ & $\begin{array}{c}\text { Family support }{ }^{b} \\
\text { P value }(r)\end{array}$ & $\begin{array}{c}\text { Significant other } \\
\text { support } \\
\text { P value }(r)\end{array}$ & $\begin{array}{c}\text { Friends Support } \\
\text { P value }(r)\end{array}$ \\
\hline PTSD Scores & $14.70(9.666)$ & $18.30(9.890)$ & $<0.001$ & $<0.001(\mathrm{r}=0.266)$ & $\begin{array}{c}<0.001 \\
(\mathrm{r}=-0.127)\end{array}$ & $\begin{array}{c}0.101 \\
(\mathrm{r}=0.045)\end{array}$ & $\begin{array}{c}0.269 \\
(\mathrm{r}=-0.030)\end{array}$ \\
\hline $\begin{array}{l}\text { Probable PTSD* } \\
\text { Not probable PTSD* }\end{array}$ & $\begin{array}{c}218(43.1 \%)^{*} \\
288(56.9 \%)^{*}\end{array}$ & $\begin{array}{c}494(59.2 \%)^{*} \\
340(40.8 \%)^{*}\end{array}$ & $\mathrm{P}<0.001^{\mathrm{C}}$ & $\mathrm{P}<0.001^{\mathrm{d}}$ & - & - & - \\
\hline Arousal score & $7.25(5.119)$ & $10.85(5.573)$ & $<0.001$ & $<0.001(\mathrm{r}=0.405)$ & $\begin{array}{c}<0.001 \\
(\mathrm{r}=-0.135)\end{array}$ & $\begin{array}{c}0.902 \\
(\mathrm{r}=0.003)\end{array}$ & $\begin{array}{c}0.026 \\
(\mathrm{r}=-0.061)\end{array}$ \\
\hline Family support score & $5.15(1.998)$ & $4.76(2.112)$ & $<0.001$ & $\begin{array}{c}<0.001 \\
(\mathrm{r}=-0.161)\end{array}$ & - & $<0.001(\mathrm{r}=0.311)$ & $<0.001(\mathrm{r}=0.233)$ \\
\hline $\begin{array}{l}\text { Significant other support } \\
\text { score }\end{array}$ & $5.53(2.032)$ & $5.53(2.060)$ & 0.945 & $\begin{array}{c}0.127 \\
(\mathrm{r}=-0.042)\end{array}$ & $\begin{array}{c}<0.001 \\
(\mathrm{r}=0.311)\end{array}$ & - & $<0.001(\mathrm{r}=0.397)$ \\
\hline Friends Support score & $5.49(1.993)$ & $5.23(2.138)$ & 0.027 & $\begin{array}{c}<0.001 \\
(\mathrm{r}=-0.098)\end{array}$ & $\begin{array}{c}<0.001 \\
(\mathrm{r}=0.233)\end{array}$ & $<0.001(\mathrm{r}=0.397)$ & - \\
\hline
\end{tabular}

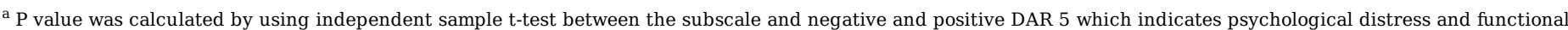
impairment related to anger.

${ }^{\mathrm{b}} \mathrm{P}$ value was calculated by using Pearson correlation between the subscale and support score.

${ }^{\mathrm{c}} \mathrm{P}$ value was calculated by using Chi-square.

${ }^{\mathrm{d}} \mathrm{P}$ value was calculated by t-independent test between DAR 5 score and probable PTSD

* These are nominal variables and the numbers refer to frequencies.
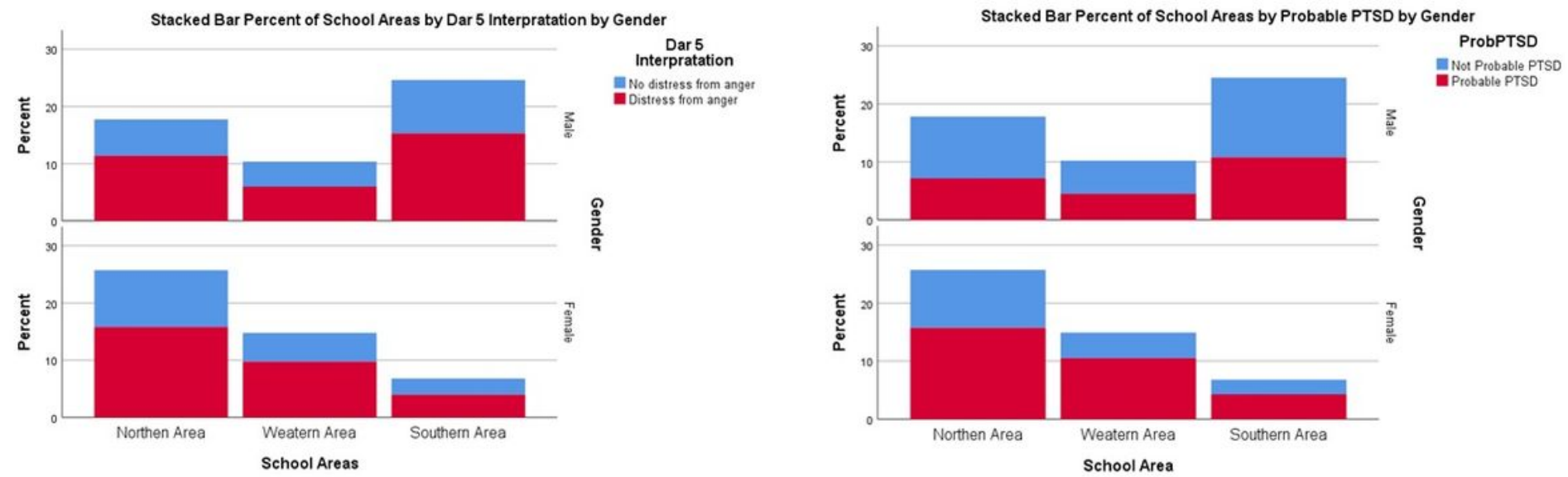

Figure 1

demonstrating PTSD and being distressed from anger prevalence according to school areas and gender.
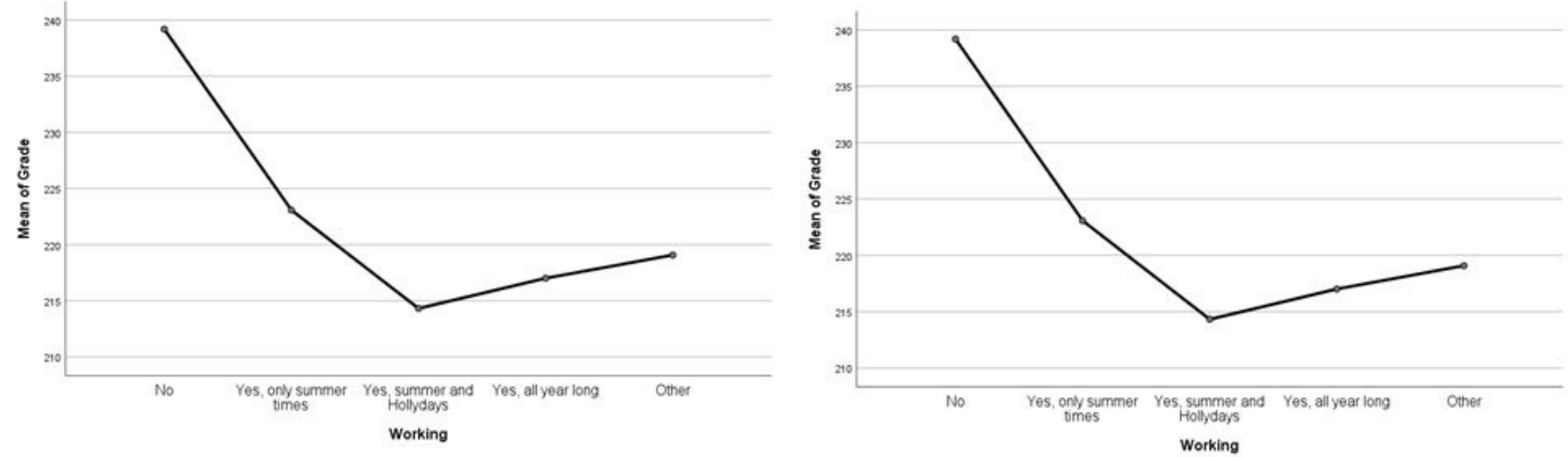

Figure 2

demonstrating mean plots of working and type of work with mean students' grade. 
TABLE 4

Comparisons between Characteristics and Physical and Mental Component Summary of SF-8

\begin{tabular}{|c|c|c|c|c|}
\hline Characteristic & $\begin{array}{l}\text { Physical component Summary (PCS) } \\
\text { M (SD) }\end{array}$ & $P$ value & $\begin{array}{c}\text { Mental Component Summary (MCS) } \\
\text { M (SD) }\end{array}$ & $P$ value \\
\hline Gender* & & & & \\
\hline $\begin{array}{l}\text { Male } \\
\text { Female }\end{array}$ & $\begin{array}{l}15.73(3.126) \\
15.27(3.222) \\
\end{array}$ & 0.008 & $\begin{array}{l}15.21(3.265) \\
13.87(3.498) \\
\end{array}$ & $<0.001$ \\
\hline $\begin{array}{l}\text { Schools } \\
\text { Northern area } \\
\text { Southern area } \\
\text { Western area } \\
\end{array}$ & $\begin{array}{l}15.78(3.154) \\
15.32(3.090) \\
15.29(3.306) \\
\end{array}$ & 0.026 & $\begin{array}{l}14.63(3.408) \\
14.40(3.621) \\
14.64(3.343) \\
\end{array}$ & 0.559 \\
\hline $\begin{array}{l}\text { Consanguinity } \\
\text { No } \\
\text { Yes third-degree relatives } \\
\text { Yes fourth-degree relatives } \\
\text { Yes but not close relatives }\end{array}$ & $\begin{array}{l}15.50(3.237) \\
15.52(2.743) \\
15.28(3.452) \\
15.48(3.143) \\
\end{array}$ & 0.962 & $\begin{array}{l}14.42(3.504) \\
14.88(3.029) \\
14.86(3.486) \\
15.29(3.210) \\
\end{array}$ & 0.042 \\
\hline $\begin{array}{l}\text { Chronic Medical Conditions } \\
\text { Negative } \\
\text { Gastroenterology } \\
\text { Pulmonology } \\
\text { Cardiology } \\
\text { Endocrinology } \\
\text { Urology } \\
\text { Nervous } \\
\text { Skeletal } \\
\text { Asthma } \\
\text { Allergy } \\
\text { Ophthalmology } \\
\text { Psychiatry } \\
\text { Two and more } \\
\text { Other }\end{array}$ & $\begin{array}{c}15.86(3.044) \\
12.80(4.658) \\
14.56(2.698) \\
12.60(4.085) \\
14.00(3.640) \\
13.33(3.830) \\
14.24(2.658) \\
13.50(3.724) \\
13.41(2.889) \\
14.91(3.166) \\
14.60(2.119) 11.00(-) \\
12.47(3.980) \\
15.00(-) \\
\end{array}$ & $<0.001$ & $\begin{array}{c}14.83(3.358) \\
12.60(2.302) \\
15.00(2.000) \\
12.80(3.707) \\
12.84(3.760) \\
13.17(4.119) \\
12.47(3.466) \\
14.19(3.146) \\
14.55(3.158) \\
13.51(3.390) \\
15.50(3.206) \\
8.50(3.536) \\
11.87(4.340) \\
9.00(-) \\
\end{array}$ & $<0.001$ \\
\hline $\begin{array}{l}\text { Having a chronic medical condition?* } \\
\text { No } \\
\text { yes }\end{array}$ & $\begin{array}{l}15.86(3.044) \\
13.81(3.366) \\
\end{array}$ & $<0.001$ & $\begin{array}{l}14.83(3.358) \\
13.38(3.541) \\
\end{array}$ & $<0.001$ \\
\hline $\begin{array}{l}\text { SES } \\
\text { Lower } \\
\text { Upper Lower } \\
\text { Upper Middle } \\
\text { Middle } \\
\text { Upper } \\
\end{array}$ & $\begin{array}{l}14.50(4.204) \\
15.27(3.336) \\
15.56(2.855) \\
15.64(3.247) \\
16.30(3.377) \\
\end{array}$ & 0.041 & $\begin{array}{l}13.33(4.390) \\
14.26(3.591) \\
14.78(3.344) \\
14.62(3.319) \\
15.19(3.375) \\
\end{array}$ & 0.021 \\
\hline $\begin{array}{l}\text { House* } \\
\text { Rented } \\
\text { Owned } \\
\end{array}$ & $\begin{array}{l}15.39(3.060) \\
15.58(3.187) \\
\end{array}$ & 0.341 & $\begin{array}{l}14.46(3.427) \\
14.63(3.450) \\
\end{array}$ & 0.460 \\
\hline $\begin{array}{l}\text { Working } \\
\text { No } \\
\text { Yes, but only in summer times } \\
\text { Yes in summer and holidays } \\
\text { Yes, all year long } \\
\text { Other times }\end{array}$ & $\begin{array}{l}15.64(3.142) \\
15.54(3.136) \\
15.15(3.204) \\
14.61(3.551) \\
16.60(1.517) \\
\end{array}$ & 0.026 & $\begin{array}{l}14.54(3.440) \\
14.93(3.405) \\
14.35(3.704) \\
14.02(3.223) \\
15.80(2.775) \\
\end{array}$ & 0.147 \\
\hline $\begin{array}{l}\text { Reported that they liked their job* } \\
\text { No } \\
\text { Yes }\end{array}$ & $\begin{array}{l}14.43(3.435) \\
15.50(3.151) \\
\end{array}$ & 0.003 & $\begin{array}{l}13.22(3.702) \\
14.97(3.290) \\
\end{array}$ & $<0.001$ \\
\hline $\begin{array}{l}\text { Reported reason for working } \\
\text { Entertainment } \\
\text { To learn or develop a skill } \\
\text { To provide personal expenses } \\
\text { To help with family expenses } \\
\text { Forced by the Family } \\
\text { Other reason } \\
\end{array}$ & $\begin{array}{l}15.77(3.307) \\
15.64(3.018) \\
14.93(3.017) \\
14.96(3.312) \\
15.50(2.380) \\
15.00(3.606) \\
\end{array}$ & 0.235 & $\begin{array}{l}15.29(3.444) \\
14.62(3.722) \\
14.14(3.549) \\
14.19(3.442) \\
13.00(3.916) \\
16.00(1.000) \\
\end{array}$ & 0.058 \\
\hline $\begin{array}{l}\text { Reported being treated badly by boss* } \\
\text { No } \\
\text { Yes }\end{array}$ & $\begin{array}{l}15.55(3.135) \\
13.52(3.418) \\
\end{array}$ & $<0.001$ & $\begin{array}{l}14.89(3.323) \\
13.11(3.809) \\
\end{array}$ & 0.001 \\
\hline $\begin{array}{l}\text { Type of work: } \\
\text { Waiter } \\
\text { Education } \\
\text { Retail Worker } \\
\text { In an office } \\
\text { Labourer } \\
\text { Handicraft } \\
\text { Industry } \\
\text { Design } \\
\text { Chef } \\
\text { Prefer Not to Say }\end{array}$ & $\begin{array}{l}15.25(3.146) \\
13.33(5.715) \\
15.23(3.281) \\
15.36(2.818) \\
15.39(3.797) \\
14.90(3.266) \\
15.90(2.625) \\
14.14(2.795) \\
17.50(0.707) \\
15.91(2.904) \\
\end{array}$ & 0.425 & $\begin{array}{c}13.91(3.513) \\
11.33(3.777) \\
14.69(3.510) \\
14.21(2.940) \\
15.36(3.382) \\
14.09(3.805) \\
15.24(2.791) \\
14.43(3.101) \\
18.50(2.121) \\
15.47(2.759) \\
\end{array}$ & 0.017 \\
\hline $\begin{array}{l}\text { Being distressed from the war noises* } \\
\text { No }\end{array}$ & $\begin{array}{l}15.93(3.017) \\
15.27(3.266)\end{array}$ & & $\begin{array}{l}15.27(3.277) \\
14.10(3.467)\end{array}$ & \\
\hline
\end{tabular}




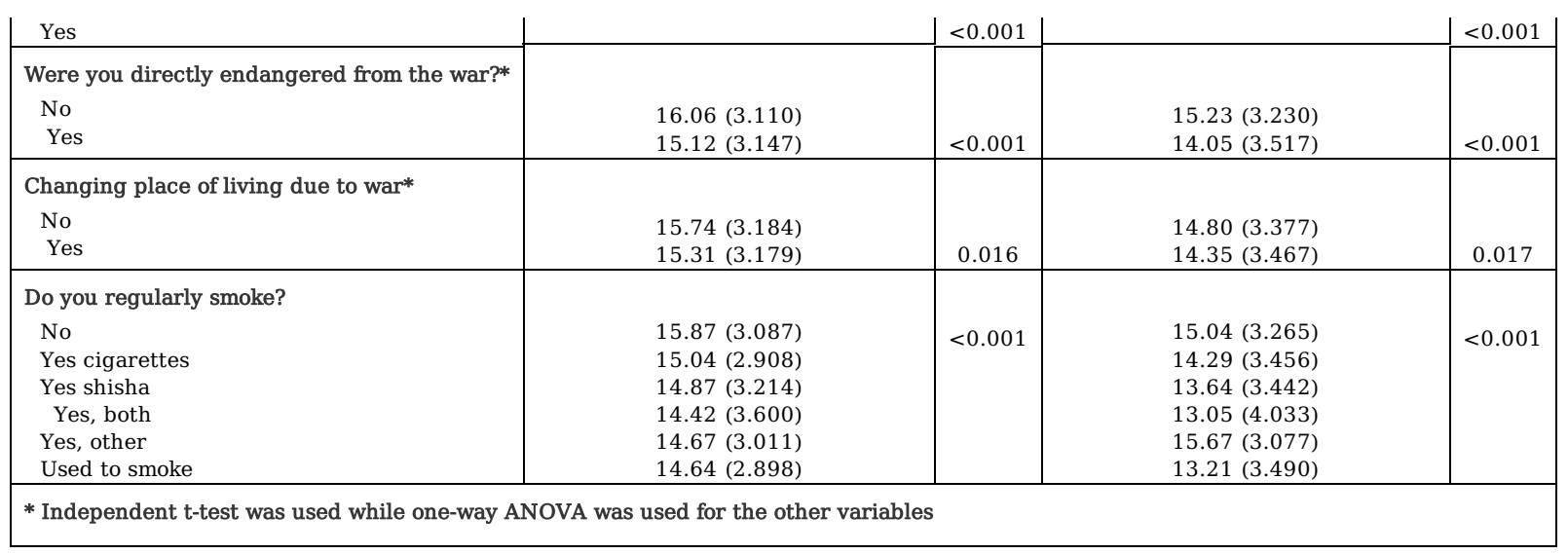


TABLE 5

Comparisons between Characteristics with having PTSD (intrusion + avoidance), negative or positive DAR, and arousal scores with other variables.

\begin{tabular}{|c|c|c|c|c|c|c|c|c|}
\hline Characteristic & Not Probable PTSD & Probable PTSD & $P$ value & Negative DAR 5 & Positive DAR 5 & $P$ value & $\begin{array}{r}\text { Arousal } \\
\text { M (SD) }\end{array}$ & $P$ value \\
\hline $\begin{array}{l}\text { Gender } \\
\text { Male } \\
\text { Female } \\
\end{array}$ & $\begin{array}{l}407 \\
229 \\
\end{array}$ & $\begin{array}{l}304 \\
413 \\
\end{array}$ & $<0.001$ & $\begin{array}{c}271 \\
240 \\
\end{array}$ & $\begin{array}{l}442 \\
400 \\
\end{array}$ & 0.847 & $\begin{array}{c}8.35(5.536) \\
10.69(5.588) \\
\end{array}$ & $<0.001$ \\
\hline $\begin{array}{l}\text { Schools } \\
\text { Northern area } \\
\text { Southern area } \\
\text { Western area } \\
\end{array}$ & $\begin{array}{l}279 \\
220 \\
137 \\
\end{array}$ & $\begin{array}{l}310 \\
204 \\
203 \\
\end{array}$ & 0.006 & $\begin{array}{c}220 \\
164 \\
127 \\
\end{array}$ & $\begin{array}{l}368 \\
261 \\
213 \\
\end{array}$ & 0.915 & $\begin{array}{l}9.65(5.552) \\
9.41(5.485) \\
9.20(6.125) \\
\end{array}$ & 0.501 \\
\hline $\begin{array}{l}\text { Consanguinity } \\
\text { No } \\
\text { Yes third-degree relatives } \\
\text { Yes fourth-degree relatives } \\
\text { Yes but not close relatives }\end{array}$ & $\begin{array}{l}466 \\
73 \\
33 \\
51\end{array}$ & $\begin{array}{c}546 \\
81 \\
29 \\
51\end{array}$ & 0.637 & $\begin{array}{c}362 \\
60 \\
28 \\
49\end{array}$ & $\begin{array}{c}648 \\
93 \\
36 \\
53 \\
\end{array}$ & 0.064 & $\begin{array}{l}9.54(5.759) \\
9.31(5.384) \\
9.77(6.039) \\
9.08(5.345) \\
\end{array}$ & 0.820 \\
\hline $\begin{array}{l}\text { Chronic Medical Conditions } \\
\text { Negative } \\
\text { Gastroenterology } \\
\text { Pulmonology } \\
\text { Cardiology } \\
\text { Endocrinology } \\
\text { Urology } \\
\text { Nervous } \\
\text { Skeletal } \\
\text { Asthma } \\
\text { Allergy } \\
\text { Ophthalmology } \\
\text { Psychiatry } \\
\text { Two and more } \\
\text { Other } \\
\end{array}$ & $\begin{array}{c}536 \\
1 \\
2 \\
7 \\
8 \\
2 \\
4 \\
7 \\
11 \\
16 \\
4 \\
0 \\
3 \\
0 \\
\end{array}$ & $\begin{array}{c}556 \\
4 \\
7 \\
8 \\
17 \\
4 \\
13 \\
9 \\
11 \\
19 \\
6 \\
2 \\
12 \\
1 \\
\end{array}$ & 0.111 & $\begin{array}{c}423 \\
2 \\
3 \\
6 \\
7 \\
3 \\
6 \\
4 \\
8 \\
12 \\
5 \\
0 \\
6 \\
1 \\
\end{array}$ & $\begin{array}{c}668 \\
3 \\
6 \\
12 \\
18 \\
3 \\
11 \\
12 \\
14 \\
21 \\
5 \\
2 \\
9 \\
0 \\
\end{array}$ & 0.867 & $\begin{array}{c}9.17(5.605) \\
10.60(3.847) \\
8.44(5.681) \\
13.20(5.281) \\
11.80(5.612) \\
15.67(1.862) \\
10.18(4.825) \\
11.06(3.941) \\
10.09(5.814) \\
11.06(6.178) \\
8.40(3.978) \\
22.00(4.243) \\
12.73(6.017) \\
13.00(-) \\
\end{array}$ & $<0.001$ \\
\hline $\begin{array}{l}\text { Do you have a chronic medical condit } \\
\text { No } \\
\text { yes }\end{array}$ & $\begin{array}{c}536 \\
65 \\
\end{array}$ & $\begin{array}{l}556 \\
113 \\
\end{array}$ & 0.002 & $\begin{array}{c}423 \\
62 \\
\end{array}$ & $\begin{array}{l}668 \\
116 \\
\end{array}$ & 0.316 & $\begin{array}{c}9.17(5.605) \\
11.28(5.531) \\
\end{array}$ & $<0.001$ \\
\hline $\begin{array}{l}\text { SES } \\
\text { Lower } \\
\text { Upper Lower } \\
\text { Upper Middle } \\
\text { Middle } \\
\text { Upper } \\
\end{array}$ & $\begin{array}{c}7 \\
112 \\
237 \\
211 \\
14 \\
\end{array}$ & $\begin{array}{c}9 \\
154 \\
231 \\
251 \\
29 \\
\end{array}$ & 0.066 & $\begin{array}{c}6 \\
91 \\
181 \\
173 \\
19 \\
\end{array}$ & $\begin{array}{c}10 \\
172 \\
290 \\
290 \\
23 \\
\end{array}$ & 0.700 & $\begin{array}{l}10.44(6.572) \\
9.94(5.964) \\
9.41(5.341) \\
9.40(5.693) \\
9.05(6.067) \\
\end{array}$ & 0.632 \\
\hline $\begin{array}{l}\text { House } \\
\text { Rented } \\
\text { Owned }\end{array}$ & $\begin{array}{l}148 \\
463 \\
\end{array}$ & $\begin{array}{l}163 \\
531 \\
\end{array}$ & 0.756 & $\begin{array}{l}108 \\
385 \\
\end{array}$ & $\begin{array}{l}202 \\
610 \\
\end{array}$ & 0.222 & $\begin{array}{l}9.71(5.543) \\
9.34(5.729) \\
\end{array}$ & 0.315 \\
\hline $\begin{array}{l}\text { Working } \\
\text { No } \\
\text { Yes, but only in summer times } \\
\text { Yes in summer and holidays } \\
\text { Yes, all year long } \\
\text { Other times }\end{array}$ & $\begin{array}{c}373 \\
153 \\
55 \\
50 \\
3 \\
\end{array}$ & $\begin{array}{c}481 \\
138 \\
48 \\
43 \\
2 \\
\end{array}$ & 0.025 & $\begin{array}{c}338 \\
105 \\
33 \\
32 \\
1\end{array}$ & $\begin{array}{c}515 \\
187 \\
71 \\
60 \\
4 \\
\end{array}$ & 0.368 & $\begin{array}{l}9.73(5.716) \\
8.67(5.628) \\
9.41(5.737) \\
9.67(5.290) \\
9.20(3.271) \\
\end{array}$ & 0.104 \\
\hline $\begin{array}{l}\text { Reported that they liked their job } \\
\text { No } \\
\text { Yes }\end{array}$ & $\begin{array}{c}50 \\
201 \\
\end{array}$ & $\begin{array}{c}52 \\
174 \\
\end{array}$ & 0.411 & $\begin{array}{c}28 \\
135 \\
\end{array}$ & $\begin{array}{c}74 \\
241 \\
\end{array}$ & 0.110 & $\begin{array}{l}9.88(5.924) \\
8.87(5.424) \\
\end{array}$ & 0.102 \\
\hline $\begin{array}{l}\text { Reported reason for working } \\
\text { Entertainment } \\
\text { To learn or develop a skill } \\
\text { To provide personal expenses } \\
\text { To help with family expenses } \\
\text { Forced by the Family } \\
\text { Other reason }\end{array}$ & $\begin{array}{c}86 \\
18 \\
53 \\
69 \\
2 \\
2 \\
\end{array}$ & $\begin{array}{c}59 \\
28 \\
58 \\
68 \\
2 \\
1\end{array}$ & 0.197 & $\begin{array}{l}50 \\
13 \\
33 \\
47 \\
2 \\
1\end{array}$ & $\begin{array}{c}94 \\
34 \\
76 \\
90 \\
2 \\
2\end{array}$ & 0.877 & $\begin{array}{c}9.15(5.548) \\
8.65(5.143) \\
9.15(5.474) \\
9.69(5.744) \\
9.50(3.317) \\
11.00(7.810) \\
\end{array}$ & 0.879 \\
\hline $\begin{array}{l}\text { Reported being treated badly by boss } \\
\text { No } \\
\text { Yes }\end{array}$ & $\begin{array}{c}223 \\
27 \\
\end{array}$ & $\begin{array}{c}181 \\
36 \\
\end{array}$ & 0.068 & $\begin{array}{c}146 \\
14 \\
\end{array}$ & $\begin{array}{c}258 \\
49 \\
\end{array}$ & 0.030 & $\begin{array}{c}8.77(5.637) \\
11.13(4.966) \\
\end{array}$ & 0.002 \\
\hline $\begin{array}{l}\text { Type of work: } \\
\text { Waiter } \\
\text { Education } \\
\text { Retail Worker } \\
\text { In an office } \\
\text { Labourer } \\
\text { Handicraft } \\
\text { Industry } \\
\text { Design } \\
\text { Chef } \\
\text { Prefer Not to Say }\end{array}$ & $\begin{array}{c}23 \\
1 \\
98 \\
8 \\
15 \\
47 \\
15 \\
3 \\
2 \\
49\end{array}$ & $\begin{array}{c}32 \\
5 \\
86 \\
6 \\
20 \\
44 \\
6 \\
4 \\
0 \\
28\end{array}$ & $0.067 * *$ & $\begin{array}{c}18 \\
2 \\
64 \\
6 \\
17 \\
21 \\
8 \\
1 \\
2 \\
32\end{array}$ & $\begin{array}{c}37 \\
4 \\
121 \\
8 \\
19 \\
68 \\
13 \\
6 \\
0 \\
46\end{array}$ & $0.109^{* *}$ & $\begin{array}{c}9.60(5.479) \\
13.83(7.705) \\
9.30(5.236) \\
9.29(4.565) \\
8.06(6.063) \\
9.98(5.955) \\
6.95(6.021) \\
11.57(6.630) \\
1.50(2.121) \\
7.35(4.944)\end{array}$ & $0.004^{* *}$ \\
\hline Being distressed from the war noises & $\begin{array}{l}293 \\
317\end{array}$ & $\begin{array}{l}218 \\
481\end{array}$ & & $\begin{array}{l}198 \\
293\end{array}$ & $\begin{array}{l}312 \\
507\end{array}$ & & $\begin{array}{c}8.19(5.287) \\
10.36(5.785)\end{array}$ & \\
\hline
\end{tabular}




\begin{tabular}{|c|c|c|c|c|c|c|c|c|}
\hline $\begin{array}{l}\text { No } \\
\text { Yes } \\
\end{array}$ & & & $<0.001$ & & & 0.423 & & $<0.001$ \\
\hline $\begin{array}{l}\text { Were you directly endangered from the war? } \\
\text { No } \\
\text { Yes }\end{array}$ & $\begin{array}{l}283 \\
321 \\
\end{array}$ & $\begin{array}{l}265 \\
433 \\
\end{array}$ & 0.001 & $\begin{array}{l}230 \\
258 \\
\end{array}$ & $\begin{array}{l}316 \\
498 \\
\end{array}$ & 0.003 & $\begin{array}{c}8.53(5.671) \\
10.23(5.584) \\
\end{array}$ & $<0.001$ \\
\hline $\begin{array}{l}\text { Changing place of living due to war } \\
\text { No } \\
\text { Yes }\end{array}$ & $\begin{array}{l}308 \\
301 \\
\end{array}$ & $\begin{array}{l}313 \\
380 \\
\end{array}$ & 0.051 & $\begin{array}{l}218 \\
267 \\
\end{array}$ & $\begin{array}{l}405 \\
412 \\
\end{array}$ & 0.106 & $\begin{array}{l}9.01(5.658) \\
9.93(5.636) \\
\end{array}$ & 0.003 \\
\hline $\begin{array}{l}\text { Do you regularly smoke? } \\
\text { No } \\
\text { Yes cigarettes } \\
\text { Yes shisha } \\
\text { Yes, both } \\
\text { Yes, other } \\
\text { Used to smoke } \\
\end{array}$ & $\begin{array}{c}435 \\
37 \\
98 \\
46 \\
4 \\
5\end{array}$ & $\begin{array}{c}461 \\
31 \\
149 \\
63 \\
2 \\
9\end{array}$ & 0.068 & $\begin{array}{c}405 \\
14 \\
56 \\
25 \\
2 \\
3\end{array}$ & $\begin{array}{c}492 \\
55 \\
190 \\
84 \\
3 \\
11 \\
\end{array}$ & $<0.001$ & $\begin{array}{c}8.96(5.619) \\
9.19(5.772) \\
10.81(5.466) \\
11.14(5.628) \\
6.50(3.937) \\
10.86(6.371) \\
\end{array}$ & $<0.001$ \\
\hline
\end{tabular}

\section{Table 6}

Demonstrates DAR 5, PTSD (intrusion + avoidance), arousal, and social support correlations with numeric variables.

\begin{tabular}{|c|c|c|c|c|c|c|c|c|c|c|c|c|}
\hline & $\begin{array}{l}\text { Negative } \\
\text { DAR } 5 \\
\text { M (SD) }\end{array}$ & $\begin{array}{l}\text { Positive } \\
\text { DAR } 5 \\
\text { M (SD) }\end{array}$ & $\begin{array}{c}\mathrm{P} \\
\text { value }^{\mathrm{a}}\end{array}$ & $\begin{array}{c}\text { P value } \\
\text { (correlation) }^{b}\end{array}$ & $\begin{array}{c}\text { Not } \\
\text { Probable } \\
\text { PTSD } \\
\text { M (SD) }\end{array}$ & $\begin{array}{l}\text { Probable } \\
\text { PTSD } \\
\text { M (SD) }\end{array}$ & $\begin{array}{c}\mathrm{P} \\
\text { value }^{\mathrm{a}}\end{array}$ & $\begin{array}{c}\text { P value } \\
\text { (correlation) }^{\mathrm{b}}\end{array}$ & $\begin{array}{c}\text { Family } \\
\text { support }^{\mathrm{c}} \\
\text { P value }(r)\end{array}$ & $\begin{array}{l}\text { Significant } \\
\text { other } \\
\text { support }^{\mathrm{c}} \\
\text { P value } \\
\text { (r) }\end{array}$ & $\begin{array}{l}\text { Friends } \\
\text { Support } \\
\text { P value } \\
\text { (r) }\end{array}$ & $\begin{array}{c}\text { Arousal P } \\
\text { value } @\end{array}$ \\
\hline $\begin{array}{l}\text { Number of people } \\
\text { living in the } \\
\text { house }\end{array}$ & $\begin{array}{c}6.26 \\
(12.453)\end{array}$ & $\begin{array}{c}5.63 \\
(2.184)\end{array}$ & 0.162 & $\begin{array}{c}0.224 \\
(\mathrm{r}=-0.034)\end{array}$ & $\begin{array}{c}5.67 \\
(1.973)\end{array}$ & $\begin{array}{c}6.03 \\
(10.516)\end{array}$ & 0.409 & $\begin{array}{c}0.871 \\
(r=0.005)\end{array}$ & $\begin{array}{c}0.090 \\
(r=-0.047)\end{array}$ & $\begin{array}{c}0.029 \\
(r=-0.061)\end{array}$ & $\begin{array}{c}0.805 \\
(r=-0.007)\end{array}$ & $\begin{array}{c}0.913 \\
(r=-0.003)\end{array}$ \\
\hline $\begin{array}{l}\text { Number of failed } \\
\text { years }\end{array}$ & $\begin{array}{c}0.06 \\
(\mathrm{r}=0.319)\end{array}$ & $\begin{array}{c}0.04 \\
(\mathrm{r}=0.213)\end{array}$ & 0.280 & $\begin{array}{c}0.451 \\
(\mathrm{r}=-0.021)\end{array}$ & $\begin{array}{c}0.06 \\
(\mathrm{r}=0.300)\end{array}$ & $\begin{array}{c}0.05 \\
(\mathrm{r}=0.215)\end{array}$ & 0.404 & $\begin{array}{c}0.370 \\
(r=-0.25)\end{array}$ & $\begin{array}{c}0.347 \\
(r=-0.026)\end{array}$ & $\begin{array}{c}0.386 \\
(\mathrm{r}=0.024)\end{array}$ & $\begin{array}{c}0.696 \\
(r=-0.011)\end{array}$ & $\begin{array}{c}0.684 \\
(\mathrm{r}=0.011)\end{array}$ \\
\hline $\begin{array}{l}\text { Number of } \\
\text { working years } \\
\text { (for people who } \\
\text { have worked) }\end{array}$ & $\begin{array}{c}2.62 \\
(1.734)\end{array}$ & $\begin{array}{c}3.03 \\
(1.934)\end{array}$ & 0.036 & $\begin{array}{c}0.307 \\
(r=0.050)\end{array}$ & $\begin{array}{c}2.81 \\
(1.878)\end{array}$ & $\begin{array}{c}3.02 \\
(1.913)\end{array}$ & 0.260 & $\begin{array}{c}0.387 \\
(\mathrm{r}=0.42)\end{array}$ & $\begin{array}{c}0.001 \\
(r=-0.159)\end{array}$ & $\begin{array}{c}0.067 \\
(\mathrm{r}=-0.090)\end{array}$ & $\begin{array}{c}0.094 \\
(r=-0.082)\end{array}$ & $\begin{array}{c}0.116 \\
(\mathrm{r}=0.077)\end{array}$ \\
\hline $\begin{array}{l}\text { Number of time } \\
\text { changing place of } \\
\text { living due to war }\end{array}$ & $\begin{array}{c}1.22 \\
(1.726)\end{array}$ & $\begin{array}{c}1.21 \\
(1.840)\end{array}$ & 0.913 & $\begin{array}{c}0.772 \\
(\mathrm{r}=0.008)\end{array}$ & $\begin{array}{c}1.13 \\
(1.823)\end{array}$ & $\begin{array}{c}1.28 \\
(1.764)\end{array}$ & 0.141 & $\begin{array}{c}0.023 \\
(r=0.065)\end{array}$ & $\begin{array}{c}0.029 \\
(r=-0.062)\end{array}$ & $\begin{array}{c}0.324 \\
(\mathrm{r}=-0.028)\end{array}$ & $\begin{array}{c}0.321 \\
(\mathrm{r}=-0.028)\end{array}$ & $\begin{array}{c}<0.001 \\
(\mathrm{r}=0.094)\end{array}$ \\
\hline $\begin{array}{l}\text { Number of close } \\
\text { people who lost } \\
\text { due to war }\end{array}$ & $\begin{array}{c}0.45 \\
(0.639)\end{array}$ & $\begin{array}{c}0.50 \\
(0.703)\end{array}$ & 0.235 & $\begin{array}{c}0.327 \\
(\mathrm{r}=0.028)\end{array}$ & $\begin{array}{c}0.45 \\
(0.618)\end{array}$ & $\begin{array}{c}0.51 \\
(0.730)\end{array}$ & 0.080 & $\begin{array}{c}<0.001 \\
(r=0.097)\end{array}$ & $\begin{array}{c}0.004 \\
(\mathrm{r}=-0.083)\end{array}$ & $\begin{array}{c}0.265 \\
(\mathrm{r}=0.032)\end{array}$ & $\begin{array}{c}0.710 \\
(r=-0.011)\end{array}$ & $\begin{array}{c}0.002 \\
(\mathrm{r}=0.091)\end{array}$ \\
\hline $\begin{array}{l}\text { Average } \\
\text { cigarettes } \\
\text { smoked daily for } \\
\text { smokers }\end{array}$ & $\begin{array}{c}10.85 \\
(10.075)\end{array}$ & $\begin{array}{c}12.46 \\
(10.836)\end{array}$ & 0.402 & $\begin{array}{c}0.540 \\
(r=0.045)\end{array}$ & $\begin{array}{c}11.84 \\
(10.754)\end{array}$ & $\begin{array}{c}12.66 \\
(10.811)\end{array}$ & 0.602 & $\begin{array}{c}0.114 \\
(r=0.115)\end{array}$ & $\begin{array}{c}0.106 \\
(\mathrm{r}=-0.118)\end{array}$ & $\begin{array}{c}0.512 \\
(r=-0.048)\end{array}$ & $\begin{array}{c}0.923 \\
(\mathrm{r}=0.007)\end{array}$ & $\begin{array}{c}0.568 \\
(\mathrm{r}=0.042)\end{array}$ \\
\hline $\begin{array}{l}\text { Average Shisha } \\
\text { smoked weekly }\end{array}$ & $\begin{array}{c}2.23 \\
(2.227)\end{array}$ & $\begin{array}{c}2.66 \\
(2.990)\end{array}$ & 0.259 & $\begin{array}{c}0.325 \\
(\mathrm{r}=0.053)\end{array}$ & $\begin{array}{c}2.53 \\
(2.704)\end{array}$ & $\begin{array}{c}2.62 \\
(2.979)\end{array}$ & 0.756 & $\begin{array}{c}0.458 \\
(r=0.040)\end{array}$ & $\begin{array}{c}0.031 \\
(r=-0.116)\end{array}$ & $\begin{array}{c}0.978 \\
(\mathrm{r}=0.002)\end{array}$ & $\begin{array}{c}0.136 \\
(r=-0.081)\end{array}$ & $\begin{array}{c}0.360 \\
(\mathrm{r}=0.049)\end{array}$ \\
\hline $\begin{array}{l}\text { Average weekly } \\
\text { hours spent on } \\
\text { TV }\end{array}$ & $\begin{array}{c}15.25 \\
(13.059)\end{array}$ & $\begin{array}{c}18.15 \\
(17.917)\end{array}$ & 0.004 & $\begin{array}{c}<0.001 \\
(\mathrm{r}=0.116)\end{array}$ & $\begin{array}{c}15.33 \\
(13.719)\end{array}$ & $\begin{array}{c}18.38 \\
(17.978)\end{array}$ & 0.002 & $\begin{array}{c}<0.001 \\
(\mathrm{r}=0.116)\end{array}$ & $\begin{array}{c}0.308 \\
(\mathrm{r}=-0.031)\end{array}$ & $\begin{array}{c}0.291 \\
(\mathrm{r}=0.032)\end{array}$ & $\begin{array}{c}0.164 \\
(\mathrm{r}=-0.042)\end{array}$ & $\begin{array}{c}<0.001 \\
(\mathrm{r}=0.104)\end{array}$ \\
\hline $\begin{array}{l}\text { Average weekly } \\
\text { hours spent on } \\
\text { the Internet }\end{array}$ & $\begin{array}{c}24.26 \\
(17.644)\end{array}$ & $\begin{array}{c}33.55 \\
(76.126)\end{array}$ & 0.011 & $\begin{array}{c}0.039 \\
(r=0.059)\end{array}$ & $\begin{array}{c}30.97 \\
(86.779)\end{array}$ & $\begin{array}{c}29.10 \\
(22.078)\end{array}$ & 0.599 & $\begin{array}{c}0.861 \\
(r=0.005)\end{array}$ & $\begin{array}{c}0.275 \\
(r=-0.032)\end{array}$ & $\begin{array}{c}0.743 \\
(\mathrm{r}=0.009)\end{array}$ & $\begin{array}{c}0.771 \\
(\mathrm{r}=0.008)\end{array}$ & $\begin{array}{c}0.134 \\
(\mathrm{r}=0.043)\end{array}$ \\
\hline $\begin{array}{l}{ }^{\mathrm{a}} \mathrm{P} \text { value is calculat } \\
{ }^{\mathrm{b}} \mathrm{P} \text { value is calculat }\end{array}$ & ed by using & independen & sample t & -test. & . & score. & & & & & & \\
\hline
\end{tabular}

